\title{
Dietary tryptophan and methionine as modulators of the European seabass (Dicentrarchus labrax) immune status and inflammatory response
}

Tese de Candidatura ao grau de Mestrado em Ciências do Mar- Recursos Marinhos

- Especialidade Aquacultura e Pescas ao Instituto de Ciências Biomédicas Abel Salazar da Universidade do Porto.

Orientador - Doutor Benjamín Costas

Categoria - Investigador Post - Doc

Afiliação - Centro Interdisciplinar de Investigação Marinha e Ambiental da Universidade do Porto

Co-orientador - Professor Doutor António Afonso

Categoria - Professor Associado

Afiliação - Instituto de Ciências Biomédicas Abel Salazar da Universidade do Porto 


\section{$\underline{\text { Acknowledgements }}$}

After over a year many were the people who contributed to this work. Here take this opportunity to show my gratitude for all the help and teaching, for the learning opportunity and for all the affection and patience.

Nothing would have been possible without the guidance and instructions of Benjamín to which goes special thanks. He has awakened in me the taste for immunology and research. I appreciated all the work opportunities beyond the thesis and for all the trust. The demonstrated friendship was essential. Thank you for your patience and jokes when you just felt like "bufar" =D.

A special thanks to Prof. Afonso for believing in me from the beginning and for the opportunity to work in his laboratory. I treasure all the advices and teachings, the words of comfort and encouragement. For being always available for doubts and corrections but especially for the friendship and affection.

Maria Ritinha I want to thank you for everything you did for me, for your patience and companionship. I treasure all that you taught me and the morning cappuccinos $\odot$. Thank you for putting up with me and my stupid questions. Our limitations and stupidities are completed with one another =D. I sincerely hope you continue to work with you. Thanks for the scientific discussions, the conversations and the motorcycle tours by Foz. This year of work would be very different without you and I glad for being able to call you a friend.

Also I had the opportunity to work directly with fantastic people. The biggest thanks goes to Carolina Barroso for all the help in the laboratory, the long conversations and companionship. I could not forget people such Joana Moura, Diogo, Mahmod and Lorena to which I leave a big thanks and hug. To Diana Viera my special thanks and gratitude. Thanks for having me put to the test and by the challenge, for the friendship and constant smile. I hope it to have awakened the taste and curiosity of research on you.

I would like to show my great appreciation to the girls and Marta Conde Sieira Patrícia Díaz-Rosales for the valuable contribution during sampling, the enormous affection and sympathy and to Rui Magalhães for the help during the samples.

I would also like to thank to Dr.Helena Peres for the essential design and diets analysis, for all the support and for always being ready to help and contribute. 
I leave all my appreciation to NUTRIMU group for the support, help and for making me feel at home. Special thanks to Professor Aires for all the help, guidance and advices.

Could not forget the many people in CIIMAR that despite not being involved in this work gave me all the support and were always there to exchange a friendly word. Special thanks to Pedro Reis for the moments of relaxation and laughter. To Ivone I thank for the kindness, patience and willingness to help.

A special word to my friends who were allways present. To my lovely Cattii I thank for the hours of phone conversations and advices.

To Pedro. For being part of my life and for believing in me. Because nothing would be possible without you.

Esta tese é dedicada á chatinha da minha irmã e aos meus pais. Obrigada pela paciência e sacrifícios. 


\section{$\underline{\text { Abstract }}$}

Amino acids (AA) regulate key metabolic pathways important to growth, reproduction and immune responses and their nutritional supply may increase immunity-related protein synthesis, thus fish may better cope with predictable harmful events. Methionine is the precursor of both polyamines and the antioxidant glutathione whereas, tryptophan is the precursor of serotonin and has been shown to restrain the fish stress response [1].

The present study aimed to study the effects of dietary supplementation of tryptophan (TRP) and methionine (MET) on the European seabass (Dicentrarchus labrax) cellular and humoral status. The supplementation effect during an inflammatory insult was also evaluated after an intraperitoneal injection with UV killed Photobacterium damselae subsp. piscicida (Phdp).

Three cost-effective isonitrogenous ( $44.9 \%$ crude protein) and isolipidic ( $14.9 \%$ crude fat) practical diets were formulated. Fish meal represented $34 \%$ of the formula. The rest of the protein fraction was achieved by means of a variable blend of soybean meal, corn and wheat gluten and wheat meal, whereas fish oil was the main fat source. Thus, the plantprotein fraction in these experimental diets was around 50\%. Moreover, L-tryptophan or Lmethionine ( $\times 2$ the requirement level) were added at the expenses of fish meal. European seabass weighing $274.7 \pm 20.4 \mathrm{~g}$ were fed the experimental diets for a period of 15 days (trial 1). At the end of the feeding trial (trial 2), fish were subjected to a peritoneal inflammation by intraperitoneally injecting UV killed Phdp $\left(10^{6} \mathrm{CFU} \mathrm{\textrm {ml } ^ { - 1 }}\right)$. Fish injected with Hank's Balanced Salt Solution (HBSS) served as controls. Six fish per dietary treatment and stimulus were sampled following 4 and $24 \mathrm{~h}$ post-injection. The haematological profile, peripheral cell dynamics as well as several plasma humoral parameters were studied in trials 1 and 2, whereas cell migration to the inflammatory focus was also studied at 4 and $24 \mathrm{~h}$ after injection in trial 2.

MET supplementation appears to exert positive effects on the European seabass immune status by improving the peripheral leucocyte response followed by higher complement activity and bactericidal capacity. Interestingly, this enhanced immunity translated in an enhancement of the cellular response and a stronger cellular recruitment to the inflammatory focus, followed by a higher peroxidase bactericidal capacity. In tryptophan supplementation a trend to augment both cell-mediated immunity and humoral capacity was observed, suggesting some degree of immunostimulation. However, tryptophan failed to improve the inflammatory response verified by decreased numbers of blood phagocytes and the lack of immune cells recruitment. The hypothesis of immune tolerance is reinforced by a general weak humoral response. 
In summary, it is suggested that methionine supplementation has a pronounced and direct influence on the innate immune response to a peritoneal inflammation. This raises the possibility to develop functional feeds as prophylactic strategies to be adopted against predictable unfavourable events. In contrast, tryptophan has shown to be incapable of improving the inflammatory response, presenting even an opposite trend with antiinflammatory effects.

Key-words: European seabass; immunomodulation; inflammation; cell response; humoral parameters; amino acids; Photobacterium damselae subsp. piscicida 


\section{$\underline{\text { Resumo }}$}

Os aminoácidos (AA) regulam vias metabólicas chave, importantes para 0 crescimento, reprodução e respostas imunitárias e a sua suplementação nutricional pode aumentar a síntese de proteínas relacionadas com a imunidade, assim como a capacidade dos peixes de lidar com situações prejudiciais. A metionina é o precursor das poliaminas e da glutationa enquanto o triptofano é o precursor da serotonina e tem sido demostrado a sua capacidade de modular a resposta ao stress em peixes. O presente estudo teve como objetivo estudar os efeitos da suplementação de triptofano (TRP) e metionina (MET) na dieta no estado celular e humoral do robalo (Dicentrarchus labrax). O efeito da suplementação durante a resposta inflamatória foi também avaliada após a injeção de Photobacterium damselae subsp. piscicida (Phdp) inativada por UV na cavidade peritoneal.

Três dietas sustentáveis, isoazotadas (proteína bruta de 44,9\%) e isolipidicas (14,9\% de gordura bruta) foram formuladas. A farinha de peixe representou $34 \%$ da fórmula. $A$ restante da fração de proteína foi conseguida por meio de uma mistura variável de farinha de soja, glúten de milho e de trigo e farinha de trigo, enquanto o óleo de peixe foi usado com fonte de gordura principal. Assim, a parte vegetal em proteína nessas dietas experimentais foi de cerca de $50 \%$. Além disso, L-triptofano ou L-metionina ( $\times 2$ o nível de exigência) foram adicionados às custas de farinha de peixe. Robalo com cerca de $274,7 \pm$ 20,4 $\mathrm{g}$ foram alimentados com as dietas experimentais por um período de 15 dias (ensaio 1). No final do período de alimentação (ensaio 2) os restantes peixes foram submetidos a

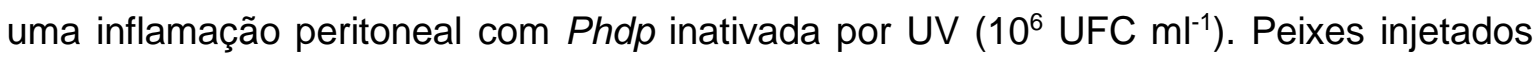
com a solução salina Hank's balanced salt solution (HBSS) serviram como controlos. Seis peixes por dieta e estímulo foram amostrados 4 e 24 horas após a injeção. O perfil hematológico e a resposta celular no sangue, bem como os vários parâmetros humorais do plasma, foram estudados nos ensaios 1 e 2. A migração celular para local da inflamação foi também estudado às 4 e 24 horas após injeção no ensaio 2.

MET parece exercer efeitos positivos sobre o estado imunológico do robalo, melhorando a resposta dos leucócitos no sangue seguindo-se uma maior atividade do sistema complemento e capacidade bactericida. Curiosamente, este reforço da imunidade traduziu-se num aumento da resposta e recrutamento celular para o foco inflamatório, com uma actividade da peroxidase e capacidade bactericida superiores. Com a suplementação de triptofano verificou-se uma tendência para aumentar tanto a imunidade mediada por células como a capacidade de resposta humoral, sugerindo certo grau de imunoestimulação. No entanto, o triptofano não conseguiu melhorar a resposta inflamatória verificando-se uma diminuição do número de fagócitos no sangue e a ausência de um 
aumento do recrutamento de células imunes ao foco inflamatório. A hipótese de tolerância imunológica é reforçada por uma fraca resposta humoral no geral.

Em resumo, neste trabalho sugere-se que a suplementação de metionina tem uma forte e direta influência sobre a resposta inflamatória, levantado a possibilidade de desenvolver alimentos funcionais como estratégias profiláticas a serem adotadas contra eventos desfavoráveis. Por outro lado, verificou-se que o triptofano parece ser incapaz de melhorar a resposta inflamatória, apresentando ainda um efeito anti-inflamatório.

Palavras-chave: Robalo; imunomodulação; inflamação; aminoácidos; resposta celular, parâmetros humorais; Photobacterium damselae subsp. piscicida. 
This thesis also includes one scientific paper in the international journal Fish \& Shellfish Immunology (under preparation) originating from the results obtained in the experimental work.

Dissemination was also achieved by means of presenting part of this work in the Aquaculture Europe conference held in San Sebastian, Spain, October 2014. This resulted in the award for the most innovative poster submitted by a student. The award is established by AquaTT and Aqualex Multimedia Consortium (AMC).

http://www.aquatt.ie/index.php?option=com_content\&view=article\&id=732 


\section{Index}

INTRODUCTION 1

WORLD AND MEDITERRANEAN AQUACULTURE

DICENTRARCHUS LABRAX 3

AQUACULTURE CONSTRAINS $\quad 4$

NUTRITION AND FISH HEALTH

THE FISH IMMUNE SYSTEM AND THE INFLAMMATORY RESPONSE

AMINO ACIDS AND INFLAMMATION

$\begin{array}{ll}\text { METHIONINE } & 10\end{array}$

TRYPTOPHAN 11

SCOPE OF THE THESIS

TRIAL 1- EFFECTS OF TRYPTOPHAN AND METHIONINE SUPPLEMENTATION ON THE EUROPEAN SEABASS (DICENTRARCHUS LABRAX) IMMUNE STATUS 14

MATERIAL AND METHODS

FORMULATION AND ANALYTICAL PROCEDURES WITH EXPERIMENTAL DIETS 14

EXPERIMENTAL DESIGN

HAEMATOLOGICAL AND ANALYTICAL PROCEDURES 17

HUMORAL PARAMETERS ANALYTICAL PROCEDURES 18

STATISTICAL ANALYSIS

RESULTS

HAEMATOLOGY

INNATE IMMUNE RESPONSE

DISCUSSION

TRIAL 2- ROLE OF TRYPTOPHAN AND METHIONINE SUPPLEMENTATION ON INFLAMMATORY RESPONSE OF EUROPEAN SEABASS (DICENTRARCHUS LABRAX)

MATERIAL AND METHODS

BACTERIAL GROWTH AND INOCULUM PREPARATION

EXPERIMENTAL DESIGN

ANALYTICAL PROCEDURES WITH HAEMATOLOGICAL PROFILE AND PERITONEAL EXUDATES 28

ANALYTICAL PROCEDURES OF HUMORAL PARAMETERS

DATA ANALYSIS $\quad 29$

STATISTICAL ANALYSIS

RESULTS

HAEMATOLOGY $\quad 30$

PERITONEAL EXUDATES

INNATE IMMUNE RESPONSE

DISCUSSION

\begin{tabular}{lr} 
CONCLUSION & 40 \\
\hline
\end{tabular}

REFERENCES $\quad 41$ 


\section{Introduction}

\section{World and Mediterranean aquaculture}

Aquaculture contributes significantly to the welfare and prosperity as the world population increase in number. This increase is followed by growing food needs and fish is an important source of nutrients and protein for most communities [2]. According to FAO, fish and resulting products have high nutritional value and are symbol of universal healthcare [2]. Data from 2009 show that fish consumption was responsible for $16.6 \%$ of all animal protein, and $6.5 \%$ of total protein consumed by the world population. With increasing world population, per-capita consumption of aquatic products requires an increase of 23 million tonnes that will have to come from aquaculture, despite the food fish production reach new maximum values every year. The increased demand for fish worldwide has created a market need that can no longer be met by existing wild fish stock [3].

Fish and fish derivatives are among the most trade food products to a global level, and that may have two distinct origins. As shown by [4], capture fisheries production have remain stable while aquaculture production has expanded, as the livestock sector with faster and sustained growth in the last five decades (Figure 1). In 2011, aquaculture represented $47 \%$ of the total seafood production in the world, valued at 97.7 billion Euros equivalent to a production of 83.7 million tonnes [5]. Nevertheless, the European Union (EU 28) aquaculture production represents only $3.2 \%$ of the world aquaculture production in volume and $8.2 \%$ in value, reaching 1.28 million tonnes and 3.5 billion Euros [2].

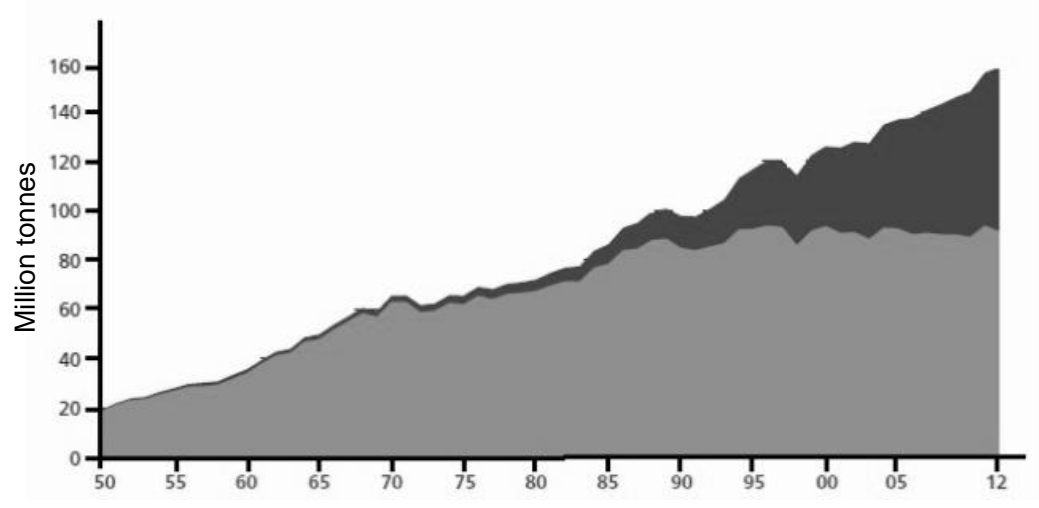

Figure 1. World seafood production by capture ( $\square$ ) and aquaculture ( $\square)$ : 1950-2012. Source: FAO, 2014 [3]. 
Marine aquaculture consists mainly of marine molluscs, finfish and crustaceans. Molluscs have the largest share of production from marine aquaculture, but have suffered a clear decline in the last decade. The rapid growth of finfish culture with an annual increase of about 9.3 per cent [2] being responsible for $52 \%$ of total sales value and $31 \%$ of sales volume of 2011 in the EU 28 [5].

Despite Mediterranean fisheries have suffered declines of about 15 per cent since 2007, the aquaculture industry has grown immensely throughout the last 40 years [2]. The Mediterranean aquaculture consists of various segments, the long-established and traditional culture of shellfish, the culture of trout and finally the culture of marine species. Current values indicate Greece as the largest producer in the Mediterranean, followed by Turkey, Spain, Italy and France [2]. The process of production, despite being facilitated by good geographical location is vulnerable to various factors such as diseases, environmental conditions, scientific and technological limitations, among others. Diseases have affected the species widely cultivated over the years, contributing to heavy losses. Another important factor is the density of production, directly related to the productivity gain, factor that may compete directly with animal welfare [2].

Portuguese aquaculture remained low until the mid-80s with its production mainly characterized by the bivalves and freshwater trout [6]. Traditionally earthen ponds constructed in old saltpans and reservoirs for fish and estuaries and lagoons for shellfish aquaculture are used, in an extensive or semi-intensive regime. Initially seen as small and familiar practices, the integration in the EU resulted in several transformations in the production incentives as well as in the production methods. As freshwater production decreased, marine aquaculture showed at the same time an overall increase when new technological improvements were implemented profiting from the available EU incentives. In the beginning of the 1990s an overall increase of marine aquaculture production was noticed, followed by a period of some fluctuation with total production was of 7987 tonnes in 2008 [6].

In Portugal, despite of the large coastal area associated to productive waters and sustainable temperature range [7], aquaculture is still manly dependent of the traditional production methods and require modernization [6]. Portugal has one of the largest coast lines in Europe, exhibiting ideal conditions for the offshore aquaculture of different aquatic species [8]. The southwest and west coasts are mostly unsuitable for proven cage technologies [9] by the intense influence of the Atlantic Ocean with stronger winds and waves. Contrary, the strong influence of the Mediterranean Sea in the southeast coast makes ocean waters relatively warm and calm all year long [6]. Therefore the extension of the platform area will have great 
economic interest, with the ability to exploit the new territory. The Estrutura de Missão para a Extensão da Plataforma Continental, is a Portuguese governmental institution whose mission is preparing a proposal to extend the Portugal continental shelf beyond 200 nautical miles [10].

According to the Portuguese Association of Fish Farmers (acronym in Portuguese, APA), Portugal reached a production of 9,000 tonnes in 2011, corresponding to around $1.6 \%$ of the total national seafood consumption. Turbot, trout, Senegalese sole, European seabass and gilthead seabream are mainly produced under intensive rearing systems in the North region (turbot, sole and trout) or semi-intensive such as earthen ponds (seabass and seabream).

\section{Dicentrarchus labrax}

The European seabass Dicentrarchus labrax (Linnaeus, 1758) (Figure 2) is commonly distributed in the Mediterranean and Black Seas and along the Eastern Atlantic coast [11]. It is an euryhaline ( $3 \%$ to full strength seawater) and eurythermic $\left(2-32^{\circ} \mathrm{C}\right)$ perciform fish, thus capable of surviving in freshwater to high salinity waters and are able to frequent coastal inshore waters, estuaries and brackish water lagoons [12].

Sexual maturity naturally occurs at 3 years in males and 4 years in females. Under farming conditions, maturity is reach at 2 years in males $( \pm 200 \mathrm{~g})$ and 3 years in females $( \pm$ 700 g) [13]. In Mediterranean female gonadal maturation starts in September and spawn occurs, once a year, in December to March in estuaries and inshore areas where salinity is close to seawater and temperature at $12-14^{\circ} \mathrm{C}$. Eggs are pelagic, small in size and hatching starts approximately 72 hours after fertilization and absolute fecundity varies from 492000 to 950000 eggs/ Kg body weight in the Mediterranean Sea [14].

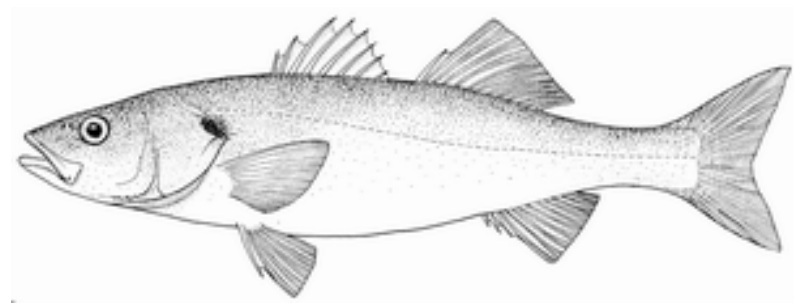

Figure 2. Dicentrarchus labrax. Source: FAO, 2012. 
The production of European seabass has a great history in the Mediterranean aquaculture. Although it remained low until the 80 's, a rapid growth was observed due to semiintensive and intensive production systems. Moreover, the development of the production was particularly rapid in Greece, representing the largest marine fish farming industry in Europe [15]. Nowadays, on-growing European seabass may take place under intensive, semiintensive or extensive systems in a variety of structures that include net cages, land based flow-through and land based recirculation systems [14]. According to Basurco [16] in Mediterranean countries $82 \%$ of farms use cages, being this the dominant intensive production on-growing system [14].

European seabass has therefore become one of the most important fish species reared in the Mediterranean aquaculture industry, yet numerous pathogens are responsible for heavy losses in its production [17]. Moreover, unfavourable environmental conditions and/or poor management practices may lead to growth rate reduction and immune suppression resulting in increased susceptibility to disease due to opportunistic pathogens [18]. Causative agents for photobacteriosis and vibriosis are responsible for relevant economic losses in the Mediterranean fish aquaculture, including seabass [17].

\section{Aquaculture constrains}

Feed supply is generally recognized as the main problem in the development of aquaculture, representing about $42 \%$ of the total production cost that requires a suitable choice [5]. According to FAO [2], 33\% of all farmed fish are produced without artificial feeding resources (Figure 3). However, this percentage has decreased reflecting the higher productivity of the species whose production requires artificial feeding, supported by the development of improved formulas [2].

Confinement, high stocking density, handling (e.g. air exposure due to grading procedures or vaccination) and transport are stress inducers highly relevant to aquaculture and have received considerable attention [19, 20, 21]. The subsequent stress response may divert the energy necessary from normal growth and metabolism to recover homeostasis [19]. 


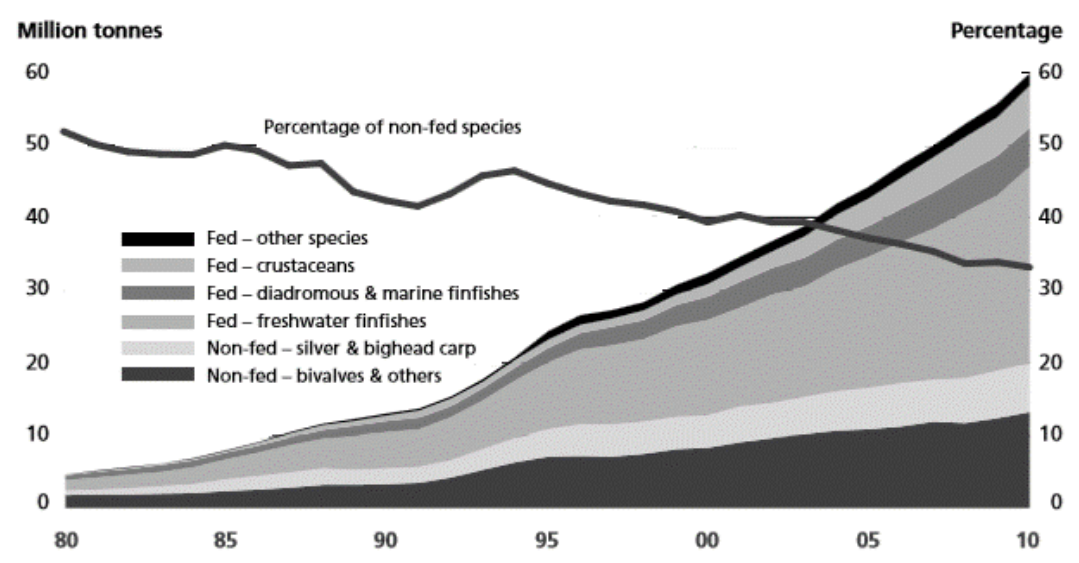

Figure 3. World aquaculture production of non-fed and fed species (1980-2010). Source: FAO, 2012 [2].

When the stressor is acute and short-term, the response pattern is stimulatory and the fish immune response shows an activating phase that specially enhances innate responses. If the stressor is chronic, the immune response shows suppressive effects and therefore the chances of an infection may increase [21]. Moreover, stressful husbandry conditions affect amino acid (AA) metabolism in fish [22, 23, 24], and under some stress situations, an increase in the requirement of certain indispensable AA may occur, which is probably related to the synthesis of proteins and other compounds related to the stress response [22]. These changes in AA are congruent with the increase of plasma cortisol levels [22, 25]. According to Mommsen et al. [26], stress affects several metabolic pathways in fish and some studies have assessed the relation between cortisol and AA (mostly FAA) concentrations in fish. In fact, AA are important regulators of key metabolic pathways such as growth and immune responses [10, $11]$.

Photobacteriosis or pasteurellosis is caused by the halophilic bacteria Photobacterium damselae subsp. piscicida (Phdp), commonly called "Pseudotuberculosis"[27, 28]. This disease has been a major limiting factor in the culture of species cultivated in the Mediterranean region [28] presenting a great economic impact, particularly by losses in Senegalese sole (Solea senegalensis), gilthead seabream (Sparus aurata) and European seabass farms [28]. Gross external signs are usually inconspicuous and there are generally no surface lesions. Internal alterations may vary depending on whether the infection is acute or chronic [27]. Phdp induces in numerous susceptible fish species a lethal septicemia with unrestricted extracellular bacterial multiplication [29]. Moreover, virulent Phdp strains secrete an exotoxin protein, AIP56, which induces the apoptotic killing of macrophages and neutrophils of teleost under natural or experimental pasteurellosis [30]. 


\section{Nutrition and fish health}

Under circumstances such as vaccination, transport, density and pathogens, the biological defence mechanisms are activated in order to recover the equilibrium, and such biological processes are sustained by endogenous sources of nutrients (Figure 4) [31]. Proper nutrition has long been recognized as a critical factor in promoting a normal growth as well as supplying the basic requirements for the immune system [32]. Poor nutrition can result in poor health even in the absence of pathogens [33], and deficiency in nutrition and infection situations are the biggest obstacles to aquaculture affecting survival, health, growth and reproduction in animals [34].

Therefore, proper nutrition plays a critical role in maintaining normal growth and health under the conditions of intensive aquaculture [32]. Growing evidence indicates that various immune responses of fish can be influenced by nutritional components of the diet, which led to the development of a new scientific discipline, nutritional immunology [31]. In fact, it has been suggested that improved dietary nitrogen formulations (including $A A$ ) may help fish coping with predictable stressful events [14].

Activation of the immune system
Pathogen $\quad \begin{gathered}\text { Cytokines } \\ \text { Acute phase protein synthesis } \\ \text { Antioxidant defences } \\ \text { Cellular response } \\ \text { Metabolic responses }\end{gathered}$

Figure 4. Concept of nutritional immunology. Source: Kiron, 2012 [31]. 


\section{The fish immune system and the inflammatory response}

The fish immune system is commonly divided into two parts, according to response speed and specificity. Initially, kicks in the non-specific immune mechanism (innate system) that acts in the same way, regardless of the type of invader, at any temperature. The rapid action of these mechanisms prevents attackers settle and multiply in the host, although there is the possibility of damaging healthy tissue due to lack of specificity [35]. Then proceeds a specific defence that takes time to operate and has a dependency on temperature [36].

The innate immune system is phylogenetically older and is present in some form in all multicellular organisms [37]. By ectothermic nature of fish, is the key defence mechanism, and although do not possess specificity for an antigen, is capable of discriminate self and nonselforganisms through recognition structures associated with molecular patterns present in microorganisms [36].

Fish have a reasonably well developed immune system based on both cellular and humoral immune responses [38, 39]. At the cellular level, the immune system is constituted of circulating white blood cells such as lymphocytes, granulocytes and monocytes. They are responsible for the initiation of phagocytosis and inflammation process and is initiated upon injury or infection [40]. The group of phagocytic cells known as monocytes/macrophages and neutrophils are responsible for the production of a variety of cellular intermediaries of inflammation that includes antibacterial peptides, complement factors, cytokines, acute-phase proteins among others [41]. Skin, gills and gut are the mucosal tissues with direct association to the immune system. As the primary barriers, mucosal tissues provide physical and chemical protection [31], with the aid of cellular and humoral components [31]. Accumulations of the innate immune related cells are found in the mucosal tissues where pathogens might enter the body. The various cells interact with each other producing a coordinated response towards pathogen elimination [42]. When external barriers are breached an inflammatory response is initiated in order to resolve the infection, repairing the damage done and establishing a new homeostasis [43].

Inflammation is a complex and multi-factorial mechanism [36, 44] responsible for the resolution of infection when the primary barriers are breached [36], repairing the damage and establishing homeostasis [31]. The effectiveness of inflammation is dependent on the ability to support a rapid and self-limiting response [45]. In mammals, the inflammatory process is initiated by local phagocytic receptors capable of recognizing pathogens, thus activating a cascade of signals leading to the onset of inflammation. Cell receptors are shaped to ensure 
that many different classes of potential pathogens can be recognized [46]. Proteins of the bacteria membrane such lipopolysaccharide (LPS) present in most Gram-negative bacteria membrane [47] are recognized by the immune cell receptors [46].

Phagocytic cells produce themselves humoral components capable of inhibit the adherence and settlement of the microorganisms realising a broad-spectrum of antimicrobial agents such as lysozyme, complement factors, anti-proteases [45, 48], bactericidal reactive oxygen species (ROS) and nitric oxide (NO) [43]. Lysozyme is a soluble enzyme, originated from several mucosal and circulating cells, including neutrophils, capable of attack the peptidoglycan layer of bacterial cell wall causing them to lyse. Complement factors can be activated directly by LPS, resulting in the lysis of the bacteria and is also responsible for the recruitment of phagocytic cells. As a measure to prevent the colonization of the pathogens, the innate immune system also presents soluble components, called anti-proteases able to inhibit the proteases released by the bacteria, limiting the digestion of proteins, source of amino acids [43].

\section{Amino acids and inflammation}

Generally classified as indispensable or dispensable [49], AA are present in all living organisms [50]. Besides their role in protein synthesis, AA regulate key metabolic pathways, important to growth, reproduction and immune responses (Table 1) [51]. Fish species possess 10 indispensable AA: arginine, histidine, isoleucine, leucine, lysine, methionine, phenylalanine, threonine, tryptophan and valine [32]. AA present important roles as signalling molecules for cells, thus their functions as key precursors for synthesis of hormones and low-molecularweight nitrogen substances and concentrations of AA metabolites (eg. polyamines, serotonin, NO, glutathione) are required for cellular functions [52]. During infection, AA are distributed away from growth and protein synthesis towards tissues and cells involved in inflammatory and immune responses and changes in AA metabolism induced by this mechanisms can generate specific requirements [53]. Moreover, it was reviewed above that stress situations induce dramatic changes in AA metabolism, modifying the AA needs, resistance to diseases and growth [54]. For instance, exercise leads to low alanine, glutamine, glutamate and branched-chain AA (i.e. leucine, isoleucine and valine) levels in rainbow trout (Oncorhynchus mykiss) [55]. 
Table 1. Overview of some important immune substances and their physiological functions which may be synthesized by amino acids and might be utilized during immune and stress responses (adapted from [34]; [56];

[50]).

\begin{tabular}{|c|c|c|}
\hline Substance & Immune function & $\begin{array}{l}\text { Amino } \\
\text { Acid }\end{array}$ \\
\hline $\begin{array}{l}\text { Nitric Oxide } \\
\text { Directly }\end{array}$ & $\begin{array}{l}\text { Signalling molecule; killing of pathogens; regulation of cytokine } \\
\text { production } \\
\text { Antioxidant }\end{array}$ & Arginine \\
\hline Directly & $\begin{array}{l}\text { Protein methylation; haemoglobin structure and function; antioxidant } \\
\text { peptides }\end{array}$ & Histidine \\
\hline Directly & Regulation of protein synthesis; activation of cytokines & Isoleucine \\
\hline Directly & Regulation of NO synthesis; antiviral activity & Lysine \\
\hline $\begin{array}{l}\text { Homocysteine } \\
\text { Cysteine } \\
\text { Taurine }\end{array}$ & $\begin{array}{l}\text { Oxidant; inhibitor of NO synthesis } \\
\text { Glutathione synthesis } \\
\text { Antioxidant; anti-inflammation }\end{array}$ & Methionine \\
\hline $\begin{array}{l}\text { Directly } \\
\text { Tyrosine }\end{array}$ & $\begin{array}{l}\text { Regulation of tetrahydrobiopterin (cofactor for NO synthesis) synthesis } \\
\text { Synthesis of neurotransmitters with neuronal function and cell metabolism }\end{array}$ & Phenylalanine \\
\hline Directly & Stimulation of lymphocyte proliferation & Threonine \\
\hline $\begin{array}{l}\text { Serotonin } \\
\mathrm{N} \text {-acetylserotonin } \\
\text { Melatonin }\end{array}$ & $\begin{array}{l}\text { Neurotransmitter; inhibition of production of inflammatory cytokines and } \\
\text { superoxide } \\
\text { Antioxidant; inhibition of production of inflammatory cytokines and } \\
\text { superoxide } \\
\text { Inhibition of production of inflammatory cytokines and superoxide }\end{array}$ & Tryptophan \\
\hline
\end{tabular}

There is growing interest on the role of AA in immune functions of fish, since increasing evidence support that AA present important features in higher vertebrates as they regulate: (1) the activation of T-lymphocytes, B-lymphocytes, natural-killer cells and macrophages; (2) the cellular redox stage, gene expression and lymphocyte proliferation; and (3) the production of antibodies, cytokines and cytokines substances as NO and superoxide [49]. Both innate and adaptive immune responses are dependent upon adequate provision of $A A$ for the synthesis of antigen-presenting molecules, immunoglobulins and cytokines [57].

Diet can have significant effects on disease resistance mechanisms, and the influence that dietary factors may have on disease outbreaks and their consumption in the syntheses of stress-related protein in cultured fish has been recognized for many years [20]. Accordingly, an optimal balance among AA in the diet and circulation, is crucial for whole-body homeostasis [49]. At the same time, requirements for protein or AA may also increase as a direct consequence of metabolic changes associated with inflammation and infection [57]. However, few studies have been conducted to assess the effect of dietary AA levels on immune responses and disease [54]. For instance, dietary arginine clearly increased some aspects of the innate immune response and disease resistance at the maximal level of supplementation in Senegalese sole [58]. 
Few studies have elucidated the effect of both methionine and tryptophan on the innate immune response, however, most of them were performed in mammals and none has been focused on the European seabass (Dicentrarchus labrax) immune system.

\section{Methionine}

Methionine affects the immune system improving both cellular and humoral immune responses and presents four main roles: i) protein synthesis; ii) glutathione (GSH) precursor; iii) synthesis of polyamines: and iv) methyl donor for methylation reactions of DNA and other molecules [59]. The need of animals for cysteine can be met by dietary methionine, and adequate amounts of both are needed for proper protein synthesis and other physiological functions of fish [60].

One of the mechanisms in which methionine may interference in the immune system is the proliferation of T cells which are sensitive to intracellular GSH and cysteine levels (Figure 5). GSH is a tripeptide synthetized from cysteine, glycine and glutamate being cysteine the major limiting AA for its synthesis [61]. However, dietary methionine can replace cysteine to support GSH synthesis in vivo [61]. GSH is able to reduce free radicals and ROS and thus may protect the cell from oxidative stress during the inflammatory process [59]. Oxidative stress has been shown to increase methionine transsulfuration in order to meet the increase cysteine demand for reduced GSH synthesis [62]. Moreover, GSH is essential for the activation of T-lymphocytes and polymorphonuclear leucocytes as well as cytokine production, and therefore mounting a successful immune response [63].

As a methyl donor for DNA methylation and polyamines synthesis [60], methionine also participates in cell proliferation and differentiation of lymphocytes by the synthesis of polyamines. Polyamines pathway is overall conservative in that spermidine and spermine, which are formed by successive additions of aminopropane, derived from decarboxylated Sadenosylmethionine [64]. 


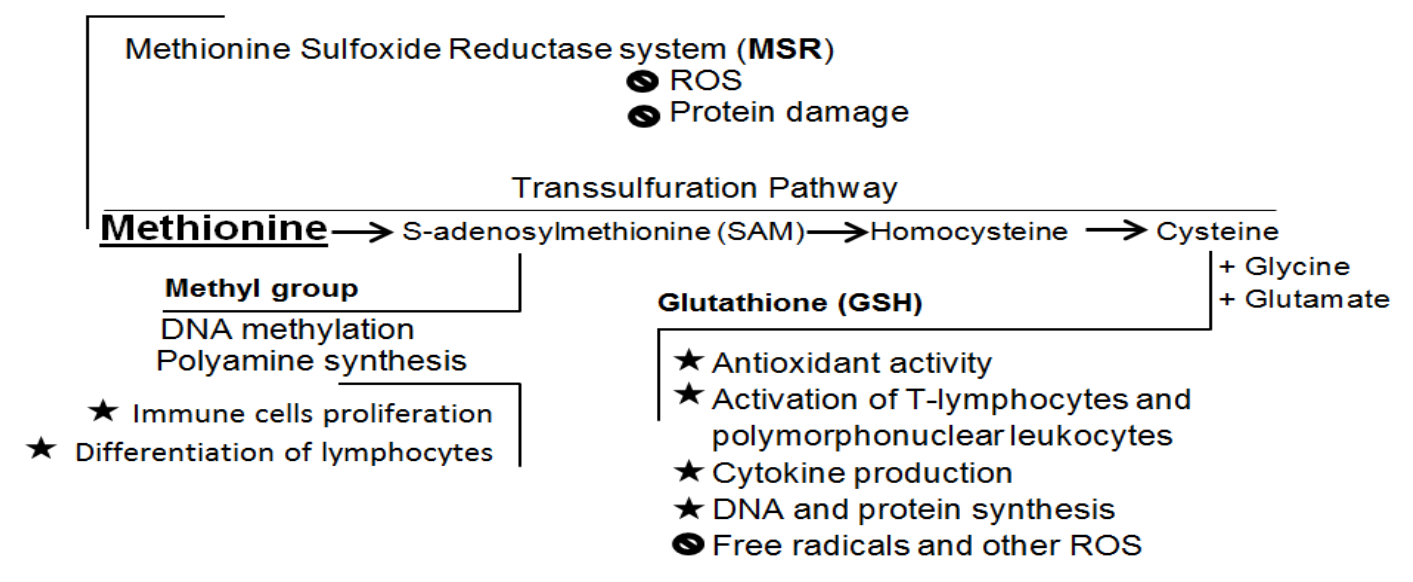

Figure 5.General methionine metabolism pathways and principal roles in the immune system. (adapted from [63];[60];[65])

\section{Tryptophan}

Tryptophan is an indispensable AA supplied in animal diets to ensure maximum growth [66]. During inflammation (Figure 6), stimulation by LPS from bacteria or certain cytokines, tryptophan metabolism (e.g. serotonin, melatonin and others [34]) increases [67]. The resulting extensive oxidative stress and tissue injury is counteracted by a melatoninor $\mathrm{N}$-acetylserotonin (NAS), an immediate precursor and metabolite of melatonin, neutralizing the toxic effect of LPS and reducing biomarkers of inflammation and oxidative stress. Melatonin and NAS have also been shown to strongly suppress LPS-lipid peroxidation [68].

The products of tryptophan metabolism are presented in Figure 6. In fish, stress situations increase plasma cortisol levels leading to changes in the metabolism of individual indispensable AA [25]. Taking this into account, tryptophan may be used to increase stress resistance by modulating cortisol levels [54]. Such therapeutic effect is a consequence of being the precursor of the neurotransmitter serotonin [50, 54]. In fact, dietary tryptophan supplementation can prevent a stress-induced cortisol surge, reduce stress-induced anorexia and cannibalism and inhibit aggression in fish [69].

During inflammation there is a progressive decline of plasma tryptophan levels, playing tryptophan catabolism a critical role in macrophage and lymphocyte functions in higher vertebrates [70,34]. The inflammatory cytokines released during immune stimulation activate indoleamine 2,3 dioxygenase (IDO) expression and its activity in macrophages by the kynurenine pathway, which catabolizes tryptophan leading to its depletion [71]. The kynurenine 
pathway is also responsible for the induction of T cells apoptosis and IDO activity consumes superoxide anions providing not only an antioxidant defence but also protecting cells from oxidative damage. For instance, a deficiency of dietary tryptophan impaired the immune response in chickens [34] whereas oral administration in rats enhanced phagocytosis by macrophages and the innate immune response [72]. In mammals, dentritic cells are also capable of expressing IDO which is associated with the acquisition of a regulatory phenotype, leading to immune tolerance. Moreover, dendritic cells coordinate adaptive immunity by integrating signals directly emanating from both infectious agents and cells of the immune system [66]. These links between innate and the more evolutionarily recent adaptive immune systems are of particular interest in fish, the oldest vertebrates to have both innate and adaptive immunity [73].

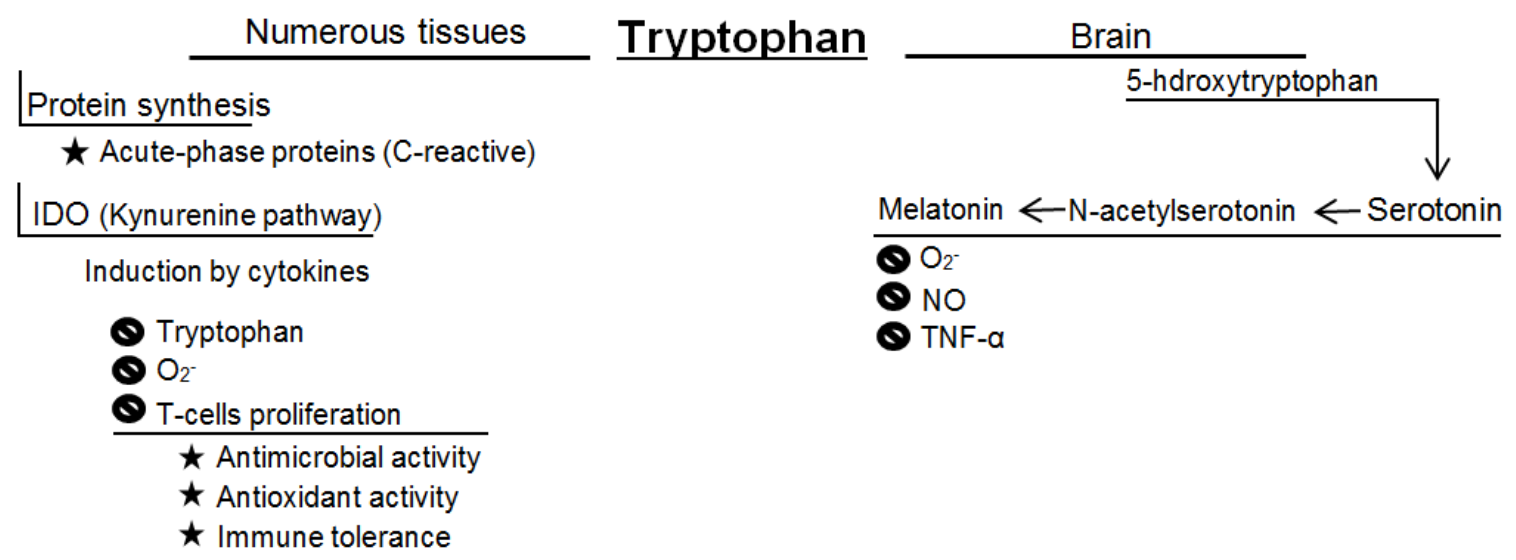

Figure 6. Simplified tryptophan metabolism pathways and principal roles in the immune system (adapted from [66];[74]). 


\section{Scope of the thesis}

Both methionine and tryptophan are AA with proven immunomodulatory effects in mammals. However, the role of dietary AA on the fish immune responses requires further attention. While few studies have elucidated the effect of both methionine and tryptophan on the innate immune response, most of them were performed in mammals and none has been focused on the European seabass immune system. Therefore, this thesis is divided in two trials with the following objectives: trial 1 aims to investigate the effects of dietary supplementation of tryptophan and methionine on the European seabass cellular and humoral status, in a way to develop functional feeds for this species; whereas the main goal of trial 2 is to allow a better understanding of the role of dietary tryptophan and methionine supplementation during the development of an inflammatory insult. Both trials should be of assistance for the improvement of functional commercial diets for European seabass, enhancing both animal health and welfare. 


\section{TRIAL 1}

\section{Effects of tryptophan and methionine supplementation on the European seabass (Dicentrarchus labrax) immune status}

\section{Material and Methods}

\section{Formulation and analytical procedures with experimental diets}

Three cost-effective isonitrogenous (44.9\% crude protein) and isolipidic (14.9\% crude fat) diets were formulated. A control fish meal (CRL) based diet was formulated, fish meal representing $34 \%$ of the formula. The rest of the protein fraction was achieved by means of a variable blend of soybean meal, corn and wheat gluten and wheat meal, whereas fish oil was the main fat source. Thus, the plant-protein fraction in these experimental diets was around $50 \%$. Moreover, L-tryptophan (TRP) or L-methionine (MET) ( $\times 2$ the requirement level) were added at the expenses of fish meal. Wheat gluten and corn gluten were chosen as complementary protein sources due to their high protein content and potential high digestibility in fish, while soybean meal is known to have both high crude protein content (45\% DM) and a reasonably balanced AA profile [75]. All dietary ingredients were finely ground, well mixed and dry pelleted in a laboratory pellet mill (California Pellet Mill, Crawfordsville, IN, USA). Formulation and proximate composition of the experimental diets are presented in Table 2 and the corresponding AA profile in Table 3. The AA patterns ( $100 \mathrm{~g}^{-1} \mathrm{AA}$ ) presented differences between experimental diets, with tryptophan and methionine being significantly higher in TRP and MET diets, respectively (Table 3).

Diets were analysed for dry matter, ash, protein, lipids and energy. The following procedures were used: dry matter after drying at 105ㅇ until constant weight; ash by incineration in a muffle furnace at $450^{\circ} \mathrm{C}$ for $16 \mathrm{~h}$; crude protein content $(\mathrm{N} \times 6.25)$ by the Kjeldahl method after acid digestion using a Kjeltec digestion and distillation units (Tecator Systems, Höganäs, Sweden; models 1015 and 1026, respectively); lipid by petroleum ether extraction using a Soxtec HT System (Tecator Systems); gross energy by direct combustion in an adiabatic bomb calorimeter (PARR model 1261, PARR Instruments, Moline, IL, USA). Diets were analysed for total AA contents. Diet samples were hydrolyzed for $23 \mathrm{~h}$ with $6 \mathrm{~N}$ hydrochloric acid at $110^{\circ} \mathrm{C}$ under nitrogen atmosphere. Samples were then derivatized with 
phenylisothiocyanate (PITC) reagent, according to the PicoTag method as described by Cohen et al. (1989)[76]. Samples and standards were separated by gradient exchange chromatography equipped with a PicoTag column, using the conditions described by Cohen et al. (1989) [76]. Chromatographic peaks were analysed with the Breeze software (Waters). Tryptophan was measured spectrophotometricaly as described elsewhere [77]. Cysteine was not determined.

Table 2. Composition and proximate analysis of the experimental diets.

\begin{tabular}{|c|c|c|c|}
\hline & \multicolumn{3}{|c|}{ Experimental diets } \\
\hline & CRL & TRP & MET \\
\hline \multicolumn{4}{|l|}{ Ingredients (\% DM) } \\
\hline Fish meal $^{1}$ & 34.1 & 33.5 & 33.2 \\
\hline Soybean meal ${ }^{2}$ & 15 & 15 & 15 \\
\hline Corn gluten ${ }^{3}$ & 10 & 10 & 10 \\
\hline Wheat gluten ${ }^{4}$ & 5 & 5 & 5 \\
\hline Wheat meal ${ }^{5}$ & 16.7 & 16.6 & 16.2 \\
\hline Fish oil & 13.9 & 13.4 & 14 \\
\hline Vitamin premix ${ }^{6}$ & 1 & 1 & 1 \\
\hline Choline chloride (50\%) & 0.5 & 0.5 & 0.5 \\
\hline Mineral premix ${ }^{7}$ & 1 & 1 & 1 \\
\hline Binder $^{8}$ & 1 & 1 & 1 \\
\hline Agar & 1 & 1 & 1 \\
\hline Dibasic calcium phosphate & 0.84 & 0.91 & 0.96 \\
\hline L-Methionine & - & - & 1.16 \\
\hline L-Tryptophan & - & 0.52 & - \\
\hline \multicolumn{4}{|l|}{$\begin{array}{c}\text { Proximate analyses (\% } \\
\text { dry weight) }\end{array}$} \\
\hline Dry matter (\%) & 95.2 & 94.3 & 94.9 \\
\hline Crude protein & 44.9 & 45.0 & 45.2 \\
\hline Crude lipid & 15.5 & 16.9 & 16.5 \\
\hline Ash & 10.5 & 10.5 & 10.4 \\
\hline
\end{tabular}

${ }^{1}$ Pesquera Centinela, Steam Dried LT, Chile (CP: 71.4\%; CL:9.3\%). Sorgal, S.A. Ovar, Portugal

2Soybean meal (CP: 54.9\%; CL:2.1\%), Sorgal, S.A. Ovar, Portugal

${ }^{3}$ Corn gluten (CP: $72.2 \%$; CL: 2.0\%), Sorgal, S.A. Ovar, Portugal

${ }^{4}$ Wheat gluten (CP: $84.4 \%$; CL: $\left.2.1 \%\right)$, Sorgal, S.A. Ovar, Portugal

${ }^{6}$ Wheat meal (CP: 13.9\%; CL: 1.8\%), Sorgal, S.A. Ovar, Portugal

${ }^{7}$ Vitamins ( $\mathrm{mg} \mathrm{kg}^{-1}$ diet): retinol, 18000 (IU kg-1 diet); calciferol, 2000 (IU kg-1 diet); alpha tocopherol, 35; menadion sodium bis., 10; thiamin, 15; riboflavin, 25; Ca pantothenate, 50; nicotinic acid, 200; pyridoxine, 5; folic acid, 10; cyanocobalamin, 0.02; biotin, 1.5; ascorbyl monophosphate, 50; inositol, 400. 
${ }^{8}$ Minerals ( $\mathrm{mg} \mathrm{kg}^{-1}$ diet): cobalt sulphate, 1.91; copper sulphate, 19.6; iron sulphate, 200; sodium fluoride, 2.21; potassium iodide, 0.78; magnesium oxide, 830; manganese oxide, 26; sodium selenite, 0.66; zinc oxide, 37.5; dicalcium phosphate, 8.02 ( $\mathrm{g} \mathrm{kg}^{-1}$ diet); potassium chloride, 1.15 ( $\mathrm{g} \mathrm{kg}^{-1}$ diet); sodium chloride, 0.4 ( $\mathrm{g} \mathrm{kg}^{-1}$ diet). ${ }^{9}$ Aquacube. Agil, UK.

Table 3. Amino acid composition $\left(\mathrm{g}_{16} \mathrm{~g}^{-1} \mathrm{~N}\right)$ of the experimental diets ${ }^{1}$.

\begin{tabular}{llll}
\hline & \multicolumn{3}{l}{ Experimental diets } \\
\cline { 2 - 4 } & CRL & TRP & MET \\
\hline Arginine & 7.74 & 7.11 & 7.02 \\
Histidine & 3.78 & 3.63 & 4.12 \\
Isoleucine & 5.05 & 4.64 & 4.71 \\
Leucine & 9.73 & 9.71 & 9.49 \\
Lysine & 6.66 & 6.96 & 6.68 \\
Methionine & 2.57 & 2.42 & 4.95 \\
Phenylalanine & 5.39 & 5.16 & 5.16 \\
Tyrosine & 4.04 & 3.96 & 3.98 \\
Threonine & 4.68 & 4.38 & 4.51 \\
Tryptophan & 1.12 & 2.24 & 1.10 \\
Valine & 5.38 & 5.10 & 5.12 \\
Aspartic Acid & 8.20 & 7.54 & 7.60 \\
Glutamic Acid & 16.39 & 16.14 & 16.09 \\
Serine & 4.15 & 4.42 & 4.29 \\
Glycine & 3.98 & 4.18 & 4.20 \\
Alanine & 4.89 & 4.92 & 4.97 \\
Proline & 4.99 & 5.50 & 4.84 \\
\hline
\end{tabular}

${ }^{1}$ Dietary cysteine levels were not determined.

\section{Experimental design}

The trial was performed at the Estação de Zoologia Marítima Dro. Augusto Nobre (Porto, Portugal). Juvenile European seabass weighing 274.7 $\pm 20.4 \mathrm{~g}$ were obtained from a commercial fish farm (Maresa, Huelva, Spain). A recirculating aerated seawater system was used and fish were distributed into 6 fiberglass tanks of 300 I water capacity, supplied with a continuous flow of filtered seawater. A 12h light/ 12h dark photoperiod was adopted, dissolved oxygen was maintained at $95 \%$, water temperature was $25 \pm 0.5^{\circ} \mathrm{C}$ and salinity averaged of $35 \pm 1 \%$. As shown in Figure 7, experimental diets were randomly assigned to duplicate tanks. Fish were fed with the experimental diets by hand to apparent satiety twice a day for a period 
of 15 days. During the feeding trial, necessary cleanings were performed and water parameters daily checked and adjusted, including nitrite and ammonia levels.

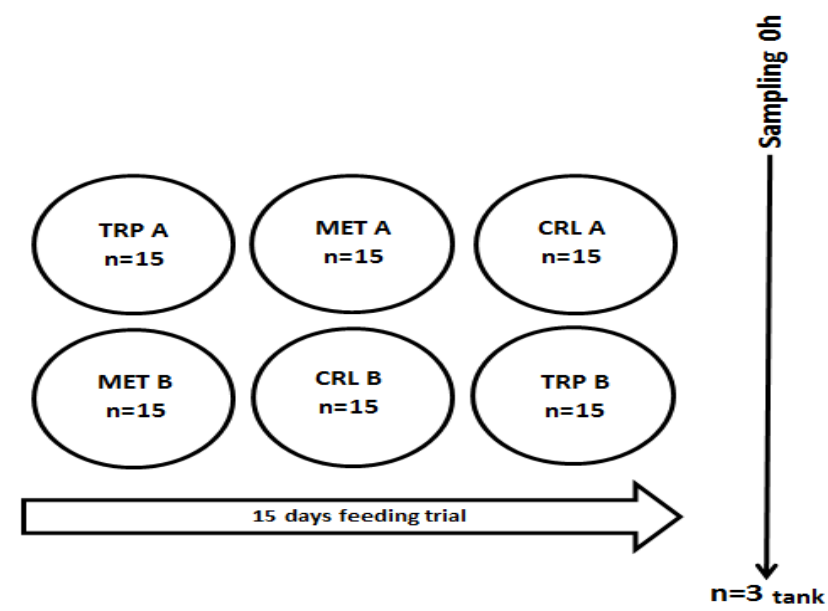

Figure 7. Representative diagram of the experimental setup.

\section{Haematological and analytical procedures}

The haematological profile comprised the analysis of the following parameters:

1) Haematocrit, which is the volume occupied by the red cells in a volume of whole blood, expressed as a percentage (Figure 8). The method consists on filling a capillary tube with blood and sealing one end of the tube with a small piece of plasticine and place the tube in the haematocrit centrifuge for $10 \mathrm{~min}$. After that, the packed cell volume or relative percentage of red blood cells (RBC) can be obtained using a graphic reader.

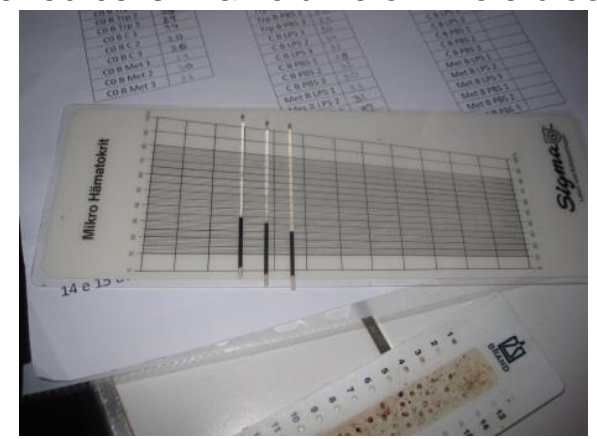

Figure 8. Heamatocrit technique.

2) Haemoglobin $(\mathrm{Hb})$, was measured by the Drabkin colorimetric method (SPINREACT, ref.:1001230, Spain)

3) Mean corpuscular volume (MCV): (Haematocrit (\%) / RBC $\left.\left(10^{6} \mu \mathrm{l}\right)\right) \times 10$

4) Mean corpuscular haemoglobin $(\mathrm{MCH})$ : (Haemoglobin (g dl) / RBC $\left.\left(10^{6} \mu \mathrm{l}\right)\right) \times 10$

5) Mean corpuscular haemoglobin concentration (MCHC): (Haemogolbin (g dl) / Haematocrit $(\%)) \times 100$

6) Counting of total RBC and white blood cells 
The solution for the white blood cells (WBC) counting resulted from a dilution 1/20 of homogenized blood in Hank's balanced salt solution (HBSS) with heparin (30units/ml), while RBC counting resulted from a dilution 1/200 of homogenized blood in HBSS with heparin at the same concentration mentioned above. Counting was then performed in a performed Neubauer chamber. Values of WBC and RBC are presented in concentration, $10^{4} \mu \mathrm{l}$ and $10^{6}$ $\mu \mathrm{l}$, respectively.

7) Preparation and examination of stained blood smears

Immediately after peripheral blood collection, blood smears were prepared, air dried, and stained with Wright's stain (Haemacolor; Merck) after fixation for 1 minute with formolethanol (10\% of $37 \%$ formaldehyde in absolute ethanol) [78]. Detection of peroxidase activity to label neutrophils was carried out by the Antonow's technique as described by Afonso et al. [79]. The slides were examined under oil immersion (1000x), and at least 200 leucocytes were counted and classified as thrombocytes, lymphocytes, monocytes and neutrophils (Figure 9). The relative percentage and absolute value $\left(\times 10^{4} / \mathrm{ml}\right)$ of each cell type was calculated.

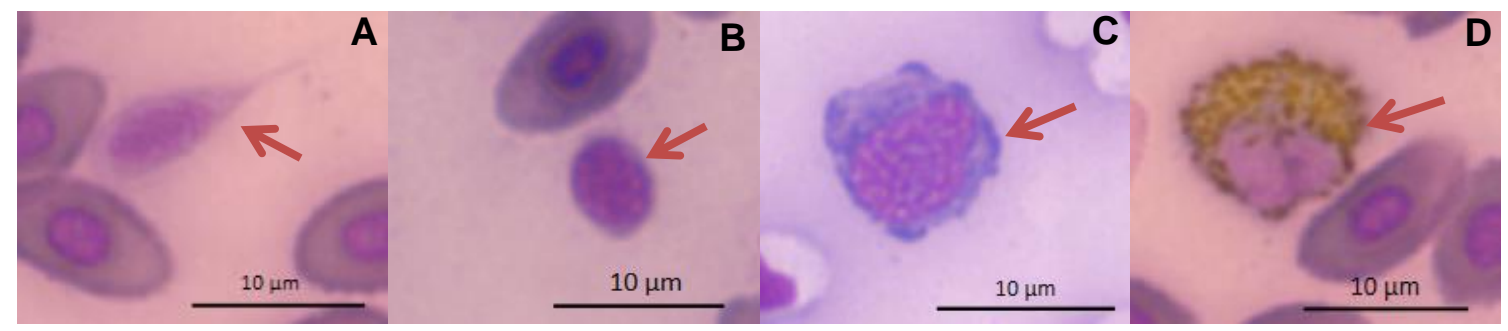

Figure 9. Blood smear stained with Wright's stain. Neutrophils were labeled using the Antonow's technique presenting abundant peroxidase-positive granules. Arrow points to: (A) thrombocyte; (B) lymphocyte; (C) monocyte; (D) neutrophil.

\section{Humoral parameters analytical procedures}

- Alternative complement pathway activity

Alternative complement pathway (ACP) activity was estimated as described by Sunyer \& Tort [38]. The following buffers were used: GVB (Isotonic veronal buffered saline), pH 7.3, containing $0.1 \%$ gelatin; EDTA-GVB, as previous one but containing $20 \mathrm{mM}$ EDTA; and MgEGTA-GVB, which is GVB with $10 \mathrm{mM} \mathrm{Mg}^{+2}$ and $10 \mathrm{mM} \mathrm{EGTA}$. Rabbit red blood cells (RaRBC; Probiologica Lda, Portugal) were used for ACP determination. RaRBC were washed four times

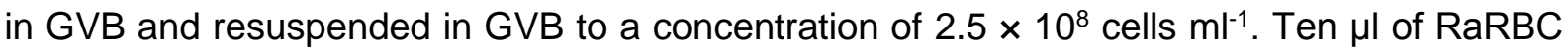
suspension were then added to $40 \mu$ of serially diluted plasma in Mg-EGTA-GVB buffer. 
Samples were incubated at room temperature for $100 \mathrm{~min}$ with regular shaking. The reaction was stopped by adding $150 \mu \mathrm{l}$ of cold EDTA-GVB. Samples were then centrifuged and the extent of haemolysis was estimated by measuring the optical density of the supernatant at 414 $\mathrm{nm}$ in a Synergy HT microplate reader, Biotek. The ACH50 units were defined as the concentration of plasma giving $50 \%$ haemolysis of RaRBC. All analysis were conducted by triplicates.

- Lysozyme

Lysozyme activity was measured using a turbidimetric assay as described by Costas et al. [58]. Briefly, a solution of Micrococcus lysodeikticus $\left(0.5 \mathrm{mg} \mathrm{ml}^{-1}, 0.05 \mathrm{M}\right.$ sodium phosphate buffer, $\mathrm{pH}$ 6.2) was prepared. To a microplate, $15 \mu \mathrm{l}$ of plasma and $250 \mu \mathrm{l}$ of the above suspension were added to give a final volume of $265 \mu \mathrm{l}$. The reaction was carried out at $25 \stackrel{\circ}{\circ} \mathrm{C}$ and the absorbance $(450 \mathrm{~nm}$ ) was measured after 0.5 and $4.5 \mathrm{~min}$ in a Synergy HT microplate reader, Biotek. Lyophilized hen egg white lysozyme (Sigma) was serially diluted in sodium phosphate buffer (0.05 M, pH 6.2) and used to develop a standard curve. The amount of lysozyme in the sample was calculated using the formula of the standard curve. All analysis were conducted in triplicates.

- Peroxidase activity

Total peroxidase activity in plasma was measured following the procedure described by Quade and Roth [80]. Briefly, $15 \mu \mathrm{l}$ of plasma were diluted with $135 \mu \mathrm{l}$ of HBSS without $\mathrm{Ca}^{+2}$

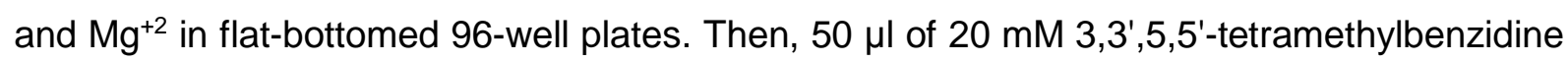
hydrochloride (TMB; Sigma) and $50 \mu \mathrm{l}$ of $5 \mathrm{mM} \mathrm{H}_{2} \mathrm{O}_{2}$ were added. The colour-change reaction was stopped after 2 min by adding $50 \mu$ of $2 \mathrm{M}$ sulphuric acid and the optical density was read at $450 \mathrm{~nm}$ in a Synergy HT microplate reader, Biotek. The wells without plasma were used as blanks. The peroxidase activity (units $\mathrm{ml}^{-1}$ plasma) was determined defining one unit of peroxidase as that which produces an absorbance change of $1 \mathrm{OD}$.

- Nitric Oxide (NO)

Total nitrite plus nitrate in plasma was analysed in duplicates using a nitrite/nitrate colorimetric method kit (Roche Diagnostics GmbH, Mannheim, Germany), adapted for 96-well microplates. Briefly, $100 \mu \mathrm{l}$ of diluted plasma samples were added to a microplate. Then, $50 \mu \mathrm{l}$ of reduced nicotinamide adenine dinucleotide phosphate (NADPH) and $4 \mu \mathrm{l}$ of the enzyme nitrate reductase (NR) were added to each well in order to reduce nitrate to nitrite. The plates were then incubated for $30 \mathrm{~min}$ at $25^{\circ} \mathrm{C}$. Afterwards, $50 \mu \mathrm{l}$ of sulfanilamide and $50 \mu \mathrm{l}$ of $\mathrm{N}-(1-$ 
naphthyl)-ethylene-diamine dihydrochloride were added and incubated for 10 min at $25^{\circ} \mathrm{C}$ (Figure 10). The absorbance was then read at $540 \mathrm{~nm}$ after the two incubation periods. Water instead of plasma was used as blank. Total nitrite was determined by comparison with a sodium nitrite standard curve. Since nitrite and nitrate are endogenously produced as oxidative metabolites of the messenger molecule NO, these compounds are considered as indicative of NO production [81].

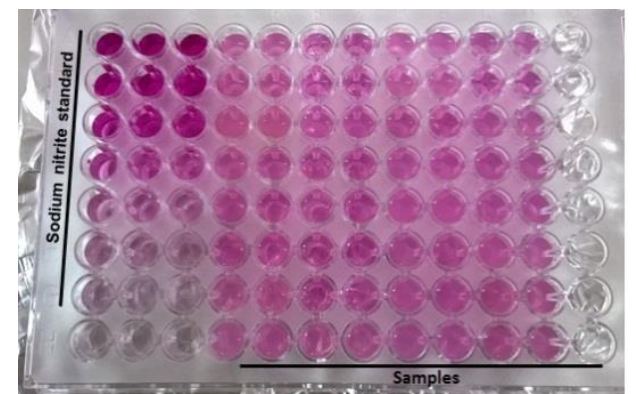

Figure 10. Microtiter plate after the second incubation period.

- Anti-protease activity

The method described by Ellis [82] was modified and adapted for 96-well microplates. Briefly, $10 \mu \mathrm{l}$ of plasma were incubated with the same volume of a trypsin solution $\left(5 \mathrm{mg} \mathrm{ml}^{-1}\right.$ in $\mathrm{NaHCO}_{3}, 5 \mathrm{mg} \mathrm{ml}^{-1}, \mathrm{pH}$ 8.3) for 10 min at $22{ }^{\circ} \mathrm{C}$ in polystyrene microtubes. To the incubation mixture, $100 \mu \mathrm{l}$ of phosphate buffer $\left(\mathrm{NaH}_{2} \mathrm{PO}_{4}, 13.9 \mathrm{mg} \mathrm{ml}^{-1}, \mathrm{pH} 7.0\right)$ and $125 \mu \mathrm{l}$ of azocasein (20 mg ml${ }^{-1}$ in $\mathrm{NaHCO}_{3}, 5 \mathrm{mg} \mathrm{ml}^{-1}, \mathrm{pH} 8.3$ ) were added and incubated for $1 \mathrm{~h}$ at $22{ }^{\circ} \mathrm{C}$. Finally, $250 \mu \mathrm{l}$ of trichloroacetic acid were added to each microtube and incubated for $30 \mathrm{~min}$ at $22^{\circ} \mathrm{C}$. The mixture was centrifuged at $10000 \times \mathrm{g}$ for $5 \mathrm{~min}$ at room temperature. Afterwards, $100 \mu \mathrm{l}$ of the supernatant was transferred to a 96 well-plate that previously contained $100 \mu \mathrm{l}$ of $\mathrm{NaOH}$ $\left(40 \mathrm{mg} \mathrm{ml}^{-1}\right.$ ) per well. The OD was read at $450 \mathrm{~nm}$. Phosphate buffer in place of plasma and trypsin served as blank whereas the reference sample was phosphate buffer in place of plasma. The percentage of trypsin activity inhibition was calculated as follows:

$$
\begin{gathered}
\% \text { non inhibited trypsin }=\frac{\text { Sample Abs. } \times 100}{\text { Abs. of the reference sample }} \\
\% \text { inhibited trypsin }=100-\% \text { non inhibited trypsin }
\end{gathered}
$$


- Bactericidal activity

Phdp strain PP3 was used in the bactericidal activity assay. Bacteria were cultured for $48 \mathrm{~h}$ at $25^{\circ} \mathrm{C}$ on tryptic soy agar (TSA; Difco Laboratories) and then inoculated into tryptic soy broth (TSB; Difco Laboratories), both supplemented with $\mathrm{NaCl}$ to a final concentration of $1 \%$ $(\mathrm{w} / \mathrm{v})$ (TSA-1 and TSB-1, respectively). Bacteria in TSB-1 medium were then cultured during $24 \mathrm{~h}$ at the same temperature, with continuous shaking (100 rpm). Exponentially growing bacteria were collected by centrifugation at $3500 \times g$ for $30 \mathrm{~min}$, resuspended in sterile HBSS and adjusted to $1 \times 10^{6} \mathrm{cfu} \mathrm{ml}^{-1}$. Plating serial dilutions of the suspensions onto TSA-1 plates and counting the number of cfu following incubation at $25^{\circ} \mathrm{C}$ confirmed bacterial concentration of the inoculum.

Plasma bactericidal activity was determined following the method of Stevens et al. [83] with modifications. Briefly, $20 \mu \mathrm{l}$ of plasma were added to duplicate wells of a U-shaped 96well plate. HBSS was added to some wells instead of plasma and served as positive control. To each well, $20 \mu \mathrm{l}$ of $P h d p\left(1 \times 10^{6} \mathrm{cfu} \mathrm{ml}^{-1}\right)$ were added and the plate was incubated for 2.5 $\mathrm{h}$ at $25 \stackrel{\circ}{\circ}$. To each well, $25 \mu \mathrm{l}$ of 3-(4,5 dimethyl-2-yl)-2,5-diphenyl tetrazolium bromide (1 mg $\mathrm{ml}^{-1}$; Sigma) were added and incubated for $10 \mathrm{~min}$ at $25^{\circ} \mathrm{C}$ to allow the formation of formazan. Plates were then centrifuged at $2000 \times g$ for $10 \mathrm{~min}$ and the precipitate (Figure 11) was dissolved in $200 \mu \mathrm{l}$ of dimethyl sulfoxide (Sigma). The absorbance of the dissolved formazan was measured at $560 \mathrm{~nm}$. Bactericidal activity is expressed as percentage, calculated from the difference between bacteria surviving compared to the number of bacteria from positive controls (100\%).

$$
\% \text { viable bacteria }=\frac{\text { Sample Abs. } \times 100}{\text { Abs. of the reference sample }}
$$

$\%$ no viable bacteria (bactericidal activity) $=100-\%$ viable bacteria

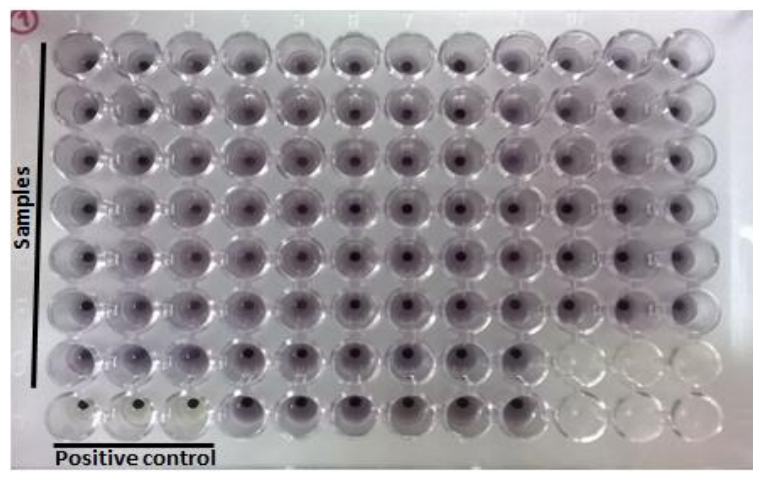

Figure 11. Precipitate formed after centrifugation 


\section{Statistical analysis}

All results are expressed as means \pm standard deviation (SD). Data were analysed for normality and homogeneity of variance and, when necessary, they were transformed before being treated statistically. Data were analysed by one-way ANOVA followed by Tukey post hoc test to identify differences in the dietary treatments. All statistical analyses were performed using the computer package STATISTICA 12 for WINDOWS. The level of significance used was $p \leq 0.05$ for all statistical tests. All the results expressed as percentage were previously arcsine transformed [84]. 


\section{Results}

\section{Haematology}

$\mathrm{Ht}, \mathrm{Hb}, \mathrm{MCV}, \mathrm{MCH}, \mathrm{MCHC}$ and $\mathrm{RBC}$ remained unchanged among dietary treatments whereas MET increased significantly total WBC compared to the control diet (Table 4).

Table 4. Haematocrit, haemoglobin, mean corpuscular volume (MCV), mean corpuscular haemoglobin (MCH), mean corpuscular haemoglobin concentration $(\mathrm{MCHC})$, red blood cells $(\mathrm{RBC})$ and white blood cells $(\mathrm{WBC})$ in European seabass fed dietary treatments during 15 days.

\begin{tabular}{lllll}
\hline \multirow{2}{*}{ Parameters } & \multicolumn{3}{c}{ Dietary treatments } \\
\cline { 3 - 5 } & & \multicolumn{1}{c}{ Control } & \multicolumn{1}{c}{ Tryptophan } & Methionine \\
\hline Haematocrit & $(\%)$ & $31.7 \pm 6.2$ & $33.5 \pm 2.8$ & $32.3 \pm 4.7$ \\
Haemoglobin & $(\mathrm{g} \mathrm{dl})$ & $4.5 \pm 1.3$ & $4.5 \pm 0.4$ & $4.4 \pm 0.7$ \\
$\mathrm{MCV}$ & $\left(\mu \mathrm{m}^{3}\right)$ & $113.5 \pm 15.2$ & $115.6 \pm 25.9$ & $110.7 \pm 22.7$ \\
$\mathrm{MCH}$ & $\left(\mathrm{gg} \mathrm{cell}^{-1}\right)$ & $16.0 \pm 2.8$ & $15.5 \pm 4.2$ & $15.0 \pm 1.7$ \\
$\mathrm{MCHC}$ & $\left({\left.\mathrm{g} 100 \mathrm{ml}^{-1}\right)}\right.$ & $14.2 \pm 2.0$ & $13.4 \pm 1.5$ & $13.8 \pm 2.2$ \\
$\mathrm{RBC}$ & $\left(\times 10^{6} \mu \mathrm{l}\right)$ & $2.8 \pm 0.7$ & $3.0 \pm 0.5$ & $3.0 \pm 0.4$ \\
$\mathrm{WBC}$ & $\left(\times 10^{4} \mu \mathrm{l}\right)$ & $2.9 \pm 0.3^{\mathrm{a}}$ & $3.2 \pm 0.5^{\mathrm{ab}}$ & $3.9 \pm 0.8^{\mathrm{b}}$ \\
\hline
\end{tabular}

Values are expressed as means $\pm S D(n=6)$. Different letters mean significant differences among dietary treatments (one-way ANOVA, $\mathrm{p} \leq 0.05$ ).

The relative proportion and absolute values of circulating leucocytes is presented in Table 5. Both percentage and concentration of the peripheral thrombocytes, lymphocytes and monocytes did not change significantly among dietary treatments while MET enhanced both the relative proportion and absolute values of peripheral neutrophils compared to CRL. Fish fed MET also presented a tendency to increase monocyte numbers. 
Table 5. Relative proportion and absolute values of peripheral blood leucocytes (thrombocytes, lymphocytes, monocytes and neutrophils) of European seabass fed dietary treatments during 15 days.

\begin{tabular}{lllll}
\hline \multirow{2}{*}{ Parameters } & \multicolumn{3}{c}{ Dietary treatments } \\
\cline { 3 - 5 } & & \multicolumn{1}{c}{ Control } & Tryptophan & Methionine \\
\hline \multirow{2}{*}{ Thrombocytes } & $(\% \mathrm{WBC})$ & $35.67 \pm 10.09$ & $40.42 \pm 6.04$ & $39.67 \pm 9.84$ \\
& $\left(\times 10^{4} \mu \mathrm{l}\right)$ & $1.03 \pm 0.36$ & $1.27 \pm 0.08$ & $1.58 \pm 0.63$ \\
Lymphocytes & $(\% \mathrm{WBC})$ & $58.50 \pm 10.15$ & $52.58 \pm 5.26$ & $50.92 \pm 8.78$ \\
& $\left(\times 10^{4} \mu \mathrm{l}\right)$ & $1.67 \pm 0.26$ & $1.71 \pm 0.44$ & $1.97 \pm 0.48$ \\
Monocytes & $(\% \mathrm{WBC})$ & $2.58 \pm 0.86$ & $2.75 \pm 0.88$ & $3.75 \pm 1.47$ \\
& $\left(\times 10^{4} \mu \mathrm{l}\right)$ & $0.08 \pm 0.03$ & $0.09 \pm 0,04$ & $0.14 \pm 0.06$ \\
Neutrophils & $(\% \mathrm{WBC})$ & $3.25 \pm 0.69^{\mathrm{a}}$ & $4.25 \pm 0.82^{\mathrm{ab}}$ & $5.67 \pm 2.40^{\mathrm{b}}$ \\
& $\left(\times 10^{4} \mu \mathrm{l}\right)$ & $0.09 \pm 0.01^{\mathrm{a}}$ & $0.14 \pm 0.04^{\mathrm{ab}}$ & $0.21 \pm 0.08^{\mathrm{b}}$ \\
\hline
\end{tabular}

Values are expressed as means $\pm S D(n=6)$. Different letters mean significant differences among dietary treatments (one-way ANOVA, $p \leq 0.05$ ).

\section{Innate immune response}

Fish fed MET showed an increase in plasma ACP and bactericidal activities compared to individuals fed CRL whereas not significant changes were observed for $\mathrm{NO}$ levels and lysozyme, peroxidase and anti-protease activities (Table 4). Still, both plasma antiprotease and peroxidase levels are in agreement with WBC numbers found in the same diet. Moreover, seabass fed TRP presented a general increase in anti-protease, ACP and bactericidal activities (Table 6).

Table 6. Innate immune parameters of European seabass fed dietary treatments during 15 days.

\begin{tabular}{lllll}
\hline \multirow{2}{*}{ Parameters } & & \multicolumn{3}{c}{ Dietary treatments } \\
\cline { 3 - 5 } & & \multicolumn{1}{c}{ Control } & \multicolumn{1}{c}{ Tryptophan } & Methionine \\
\hline ACH50 & $($ units/ ml $)$ & $73.20 \pm 15.12^{\mathrm{a}}$ & $94.52 \pm 22.11^{\mathrm{ab}}$ & $101.27 \pm 32.97^{\mathrm{b}}$ \\
Lysozyme & $(\mu \mathrm{g} / \mathrm{mg}$ protein $)$ & $3.84 \pm 0.98$ & $2.88 \pm 0.87$ & $2.93 \pm 1.47$ \\
Peroxidase & $(\mathrm{OD} 450 \mathrm{~nm})$ & $0.572 \pm 0.228$ & $0.584 \pm 0.156$ & $0.768 \pm 0.202$ \\
Nitric oxide & $(\mu \mathrm{M})$ & $189.64 \pm 57.92$ & $146.12 \pm 42.38$ & $153.27 \pm 45.98$ \\
Antiprotease activity & $(\%)$ & $50.82 \pm 9.28$ & $54.68 \pm 10.37$ & $55.39 \pm 7.01$ \\
Bactericidal activity & $(\%)$ & $11.56 \pm 6.23^{\mathrm{a}}$ & $15.96 \pm 10.42^{\mathrm{ab}}$ & $23.29 \pm 11.55^{\mathrm{b}}$ \\
\hline
\end{tabular}

Values are expressed as means \pm SD $(n=6)$. Different letters mean significant differences among dietary treatments (one-way ANOVA, $p \leq 0.05$ ). 


\section{Discussion}

Dietary tryptophan and methionine have been proven to have important roles in the mammalian immune response, and their capacity to modulate metabolic pathways involved in the development of an improved immune response and the associated mechanisms are recognized for both AA $[64,65,66]$. In the present work, fish were fed diets supplemented with tryptophan or methionine levels above the requirement for normal growth for European seabass. Therefore, seabass responses when fed with these two diets are certainly of interest to the aquaculture stakeholders.

In the present study, the overall haematological profile was not significantly altered by the supplementation of both TRP and MET, while a significantly higher concentration of WBC was observed in fish fed MET after the feeding trial which translated in higher neutrophil numbers. An increase of WBC was also observed in juvenile Jian carp (Cyprinus carpio) fed graded levels of methionine hydroxy analogue, a common used synthetic methionine source posteriorly translating in an increased survival rate and a stronger humoral a cellular response [85]. In this study the observed higher neutrophil numbers following peripheral blood counting in fish fed MET could be explained by the increased methyl groups available for polyamine synthesis [60]. Therefore, this enhanced WBC response mounted by individuals fed MET may be important during an early response to infection or inflammation. This increased leucocyte response is further supported by the improved ACP and bactericidal activities found, suggesting an increased capacity to cope with a bacterial infection. Complement proteins can stimulate phagocytosis by opsonizing pathogens, a process that is mediated by complement receptors on the surface of phagocytic cells [86]. Considering the role of both macrophages and neutrophils on phagocytising bacteria, it is likely that individuals fed MET presented an enhanced level of protection than fish fed $C R L$ in the resistance to a bacterial infection. Similarly, Costas [50] have recently observed that Senegalese sole fed a diet with higher methionine levels (among other indispensable AA) than the control diet increased plasma ACP activity after 12 weeks of feeding. Tang et al. [87] found that for Jian carp, methionine supplementation increased complement activity, which is also in agreement with our results.

The increase in leucocyte numbers observed in the present study, particularly the clear augmentation of circulating neutrophils and the tendency of higher monocyte numbers in fish fed MET, together with the increase in ACP and bactericidal activities, demonstrates that dietary manipulation by increasing key AA can up-regulate innate immune mechanisms even in the absence of infection. Still, the lack of differences in lysozyme and peroxidase activities remains to be uncovered since neutrophils are thought to be the source of plasma lysozyme 
and peroxidase [88, 82], and increases in lysozyme and peroxidase levels have been associated with increases in neutrophil numbers [89]. This may be explained by the absence of an activation factor such as bacterial infection. Neutrophils are equipped with several antimicrobial systems that are released to the extracellular medium when activated, to the destruction of the infectious microorganisms [90]. The production of lysozyme is enhanced as response to a stimulation, relative to non-stimulated specimens [43], A similar outcome has been observed in Atlantic salmon treated with yeast $\beta$-glucan and LPS [91].

Although not significantly different, a tendency of tryptophan supplementation to present higher levels of total peripheral leucocytes and neutrophils relative to controls was observed in this study, suggesting that this particular AA may also have an important role in cell proliferation [92]. For instance, tryptophan administration in rats stimulates ornithine decarboxylase rate-controlling enzyme in the biosynthesis of polyamines [92], which presents important roles for stabilizing DNA structure, DNA double strand-break repair pathway and as antioxidant. Therefore, ornithine decarboxylase is an essential enzyme for cell growth, producing the polyamines necessary to stabilize newly synthesized DNA [93]. Likewise, fish fed TRP also showed an increase in plasma ACP and bactericidal activities similar to fish fed MET, suggesting some degree of immunostimulation. The role of tryptophan in the serotonin and subsequent melatonin biosynthesis in the brain [1], can explain this event. Serotonin is known to directly influence plasma cortisol levels, by reducing them, which is correlated to multiple aspects of the innate immune defence mechanism in fish [58]. In fact melatonin administration enhanced several innate immune responses such as peroxidase, reactive oxygen intermediates and cell-mediated cytotoxic activities in the gilthead seabream Cuesta et al. [94]. 


\section{Trial 2}

\section{Role of tryptophan and methionine supplementation on inflammatory response of European seabass (Dicentrarchus labrax)}

\section{Material and Methods}

\section{Bacterial growth and inoculum preparation}

Phdp, strain PP3, was kindly provided by Dr. Ana do Vale (Institute for Molecular and Cell Biology, University of Porto, Portugal) and isolated from yellowtail (Seriola quinqueradiata; Japan) by Dr Andrew C. Barnes (Marine Laboratory, Aberdeen, UK). To prepare the inoculum for injection into the fish peritoneal cavities, stocked bacteria were cultured for $48 \mathrm{~h}$ at $22{ }^{\circ} \mathrm{C}$ on $\mathrm{TSA}_{1}$ and then inoculated into TSBs and cultured overnight at the same temperature, with continuous shaking (100 rpm). Exponentially growing bacteria were collected by centrifugation at $3500 \times g$ for $30 \mathrm{~min}$, resuspended in sterile HBSS and adjusted to $1 \times 10^{6} \mathrm{cfu} \mathrm{ml}^{-1}$ according to Costas et al. [95]. Bacteria were then killed by ultraviolet (UV) exposure for $2 \mathrm{~h}$. Loss of bacterial viability following UV killing was confirmed by plating resulting cultures on $\mathrm{TSA}_{1}$ plates and failing to see any bacterial growth.

\section{Experimental design}

The trial was performed at the Estação de Zoologia Marítima Dro. Augusto Nobre (Porto, Portugal). European seabass juveniles weighing $274.7 \pm 20.4 \mathrm{~g}$ were obtained from a commercial fish farm (Maresa, Huelva, Spain). A recirculating aerated seawater system was used and fish were distributed into 6 fiberglass tanks of 300 I water capacity, supplied with a continuous flow of filtered seawater. A 12h light/ 12h dark photoperiod was adopted, dissolved oxygen was maintained at $95 \%$, water temperature was $25 \pm 0.5^{\circ} \mathrm{C}$ and salinity averaged of $35 \pm 1 \%$.

This trial was performed following trial 1 as shown in Figure 12. Therefore, following 15 days of feeding dietary treatments, individuals were anesthetized by immersion in 2phenoxyethanol (1500 ppm; Sigma) and intraperitoneally (i.p.) injected either with HBSS 
(control solution) or UV killed Phdp $\left(1 \times 10^{6} \mathrm{cfu} \mathrm{m}^{-1}\right)$. Afterwards, stimulated specimens were reallocated in duplicates in the same recirculated seawater system according to dietary treatments and stimuli. Fish were then sampled at 4 and 24 hours after i.p. injection with experimental sampling procedures identical during both periods. Fish were fasted for $18 \mathrm{~h}$ prior i.p. injection and during the following $24 \mathrm{~h}$.
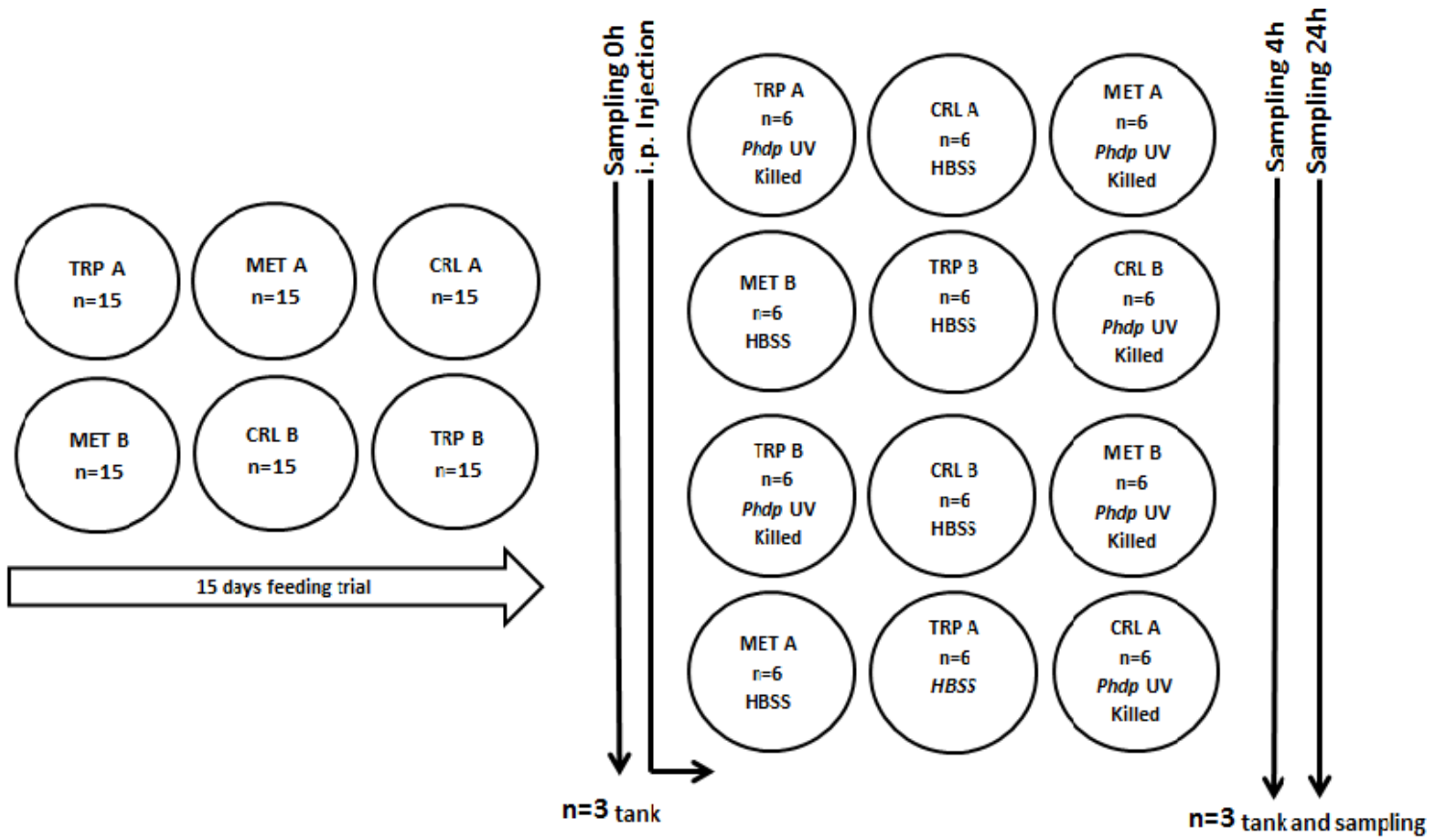

Figure 12. Experimental trial draft.

\section{Analytical procedures with haematological profile and peritoneal}

The haematological profile was performed essentially as described in the material and methods from Trial 1.

The peritoneal cells were collected according to the procedure described initially for mice by Silva et al. [96] and posteriorly adapted for fish by Afonso et al. [97]. Briefly, following fish euthanasia and bleeding by the caudal vessels, cold HBSS supplemented with 30 units heparin $\mathrm{ml}^{-1}$ was injected into the peritoneal cavity of fish ( $5 \mathrm{ml}$ per fish). Then, the peritoneal area was slightly massaged in order to disperse the peritoneal cells in

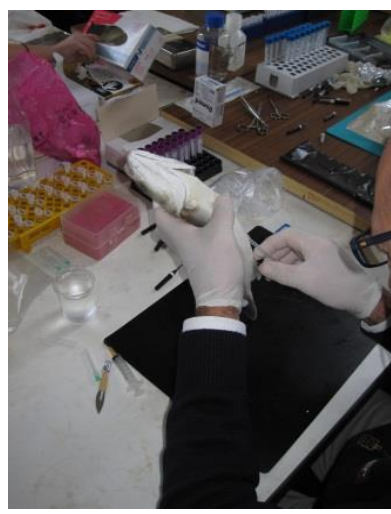

Figure 13. Collection of peritoneal exudate 
the injected HBSS. The i.p. injected HBSS containing suspended cells was finally collected (Figure 13).

Total peritoneal cell counts were performed with a Neubauer chamber according to procedures described above. Cytospin preparations were then made with a THARMAC Cellspin apparatus and stained as indicated above for blood smears. The lymphocytes, macrophages and neutrophils in the peritoneal exudates were differentially counted, and the percentage of each cell type was established after counting a minimum of 300 cells per slide (Figure 14). The concentration $\left(\times 10^{4} \mathrm{ml}^{-1}\right)$ of each leucocyte type was also calculated.

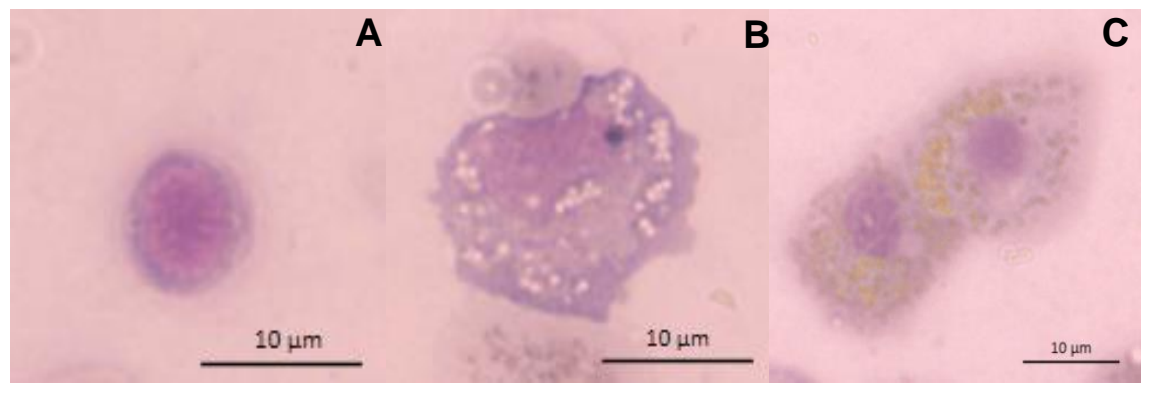

Figure 14. Cytospin preparation of peritoneal exudate stained with Wright's stain. Preparation was stained for peroxidase detection using Antonow's technique. (A) lymphocyte; (B) monocyte; (C) neutrophils.

\section{Analytical procedures of humoral parameters}

Plasma NO levels and anti-protease, lysozyme, peroxidase, ACP and bactericidal activities were performed as described above.

\section{Data analysis}

Haematological parameters were calculated as indicated above. Fold change levels (means \pm SD) were calculated by dividing each parameter value from fish i.p. injected with UV Killed Phdp by the mean value from control fish, i.p. injected with HBBS, minus one. Fold values higher than 0 express an increase and lower than 0 a decrease in the parameters assessed relative to fish i.p. injected with HBSS (control solution).

\section{Statistical analysis}

Data were analysed for normality and homogeneity of variance and, when necessary, transformed before being treated statistically. All data expressed as percentage were arcsine transformed [84]. Fold-change values were analysed by two-way ANOVA, with time and diet 
as factors. Both procedures were followed by Tukey post hoc test to identify differences in the experimental treatments. All statistical analyses were performed using the computer package STATISTICA 12 for WINDOWS. The level of significance used was $p \leq 0.05$ for all statistical tests.

\section{Results}

\section{Haematology}

Haematocrit increased significantly in fish fed MET compared to fish fed CRL following inoculation with the inactivated bacteria (Table 7), while $\mathrm{MCHC}$ decreased in fish fed both the TRP and MET diets. An increase of RBC following injection in the peritoneal cavity was observed in all dietary treatments. Similarly, an augmentation of total WBC with time in all groups and in fish fed the MET diet was also observed.

Fold change values of peripheral blood leucocytes are presented in Table 8. Circulating thrombocyte numbers in fish fed MET decreased compared to fish fed TRP at $4 \mathrm{~h}$ post-injection but no differences relatively to fish fed the control diet were observed in both experimental groups. Fish fed TRP, but not the other diets, showed decreasing peripheral thrombocyte numbers from $4 \mathrm{~h}$ to $24 \mathrm{~h}$ following inflammation. Lymphocytosis was observed at $4 \mathrm{~h}$ but not at $24 \mathrm{~h}$ post-injection in fish fed MET compared to fish fed CRL and TRP. At $24 \mathrm{~h}$ following inflammation, fish fed MET presented monocytosis compared to fish fed CRL and TRP. Neutrophil numbers increased from $4 \mathrm{~h}$ to $24 \mathrm{~h}$ in all experimental groups, and were lower in fish fed TRP than in the other groups. 
Table 7. Fold change values of haematocrit, haemoglobin, mean corpuscular volume (MCV), mean corpuscular haemoglobin (MCH), mean corpuscular haemoglobin concentration (MCHC), red blood cells (RBC) and white blood cells (WBC) in European seabass fed dietary treatments at 4 and $24 \mathrm{~h}$ after peritoneal inflammation.

\begin{tabular}{|c|c|c|c|c|c|c|c|}
\hline \multirow{3}{*}{\multicolumn{2}{|c|}{ Parameters }} & \multicolumn{6}{|c|}{ Dietary treatments } \\
\hline & & \multicolumn{2}{|c|}{ Control } & \multicolumn{2}{|c|}{ Tryptophan } & \multicolumn{2}{|c|}{ Methionine } \\
\hline & & $4 \mathrm{~h}$ & $24 \mathrm{~h}$ & $4 \mathrm{~h}$ & $24 \mathrm{~h}$ & $4 \mathrm{~h}$ & $24 \mathrm{~h}$ \\
\hline Haematoc & \multirow{7}{*}{ 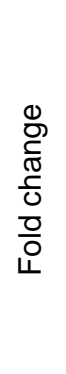 } & $0.11 \pm 0.07$ & $-0.02 \pm 0.12$ & $0.08 \pm 0.03$ & $0.10 \pm 0.09$ & $0.15 \pm 0.07$ & $0.12 \pm 0.09$ \\
\hline Haemoglo & & $0.11 \pm 0.06$ & $0.21 \pm 0.16$ & $0.02 \pm 0.11$ & $-0.01 \pm 0.24$ & $0.69 \pm 0.18$ & $0.14 \pm 0.06$ \\
\hline MCV & & $0.00 \pm 0.26$ & $-0.22 \pm 0.18$ & $-0.20 \pm 0.18$ & $-0.12 \pm 0.16$ & $0.13 \pm 0.11$ & $-0.16 \pm 0.25$ \\
\hline $\mathrm{MCH}$ & & $0.06 \pm 0.06$ & $0.21 \pm 0.12$ & $-0.01 \pm 0.17$ & $-0.12 \pm 0.08$ & $-0.12 \pm 0.17$ & $-0.03 \pm 0.05$ \\
\hline $\mathrm{MCHC}$ & & $0.06 \pm 0.05$ & $0.21 \pm 0.12$ & $-0.01 \pm 0.18$ & $-0.12 \pm 0.09$ & $-0.12 \pm 0.17$ & $-0.03 \pm 0.06$ \\
\hline $\mathrm{RBC}$ & & $0.27 \pm 0.19$ & $0.36 \pm 0.19$ & $0.13 \pm 0.14$ & $0.33 \pm 0.14$ & $0.14 \pm 0.11$ & $0.41 \pm 0.31$ \\
\hline WBC & & $-0.13 \pm 0.17$ & $0.49 \pm 0.37$ & $-0.13 \pm 0.22$ & $0.31 \pm 0.24$ & $0.65 \pm 0.48$ & $0.81 \pm 0.45$ \\
\hline
\end{tabular}

Two-way ANOVA

\begin{tabular}{ccccccc}
\hline Parameters & Time & Diet & Time $\times$ Diet & Control & Tryptophan & Methionine \\
\hline Haematocrit & ns & 0.025 & ns & a & ab & b \\
Haemoglobin & ns & ns & ns & - & - & - \\
MCV & ns & ns & ns & - & - & - \\
MCH & ns & ns & ns & - & - & - \\
MCHC & ns & $<0.001$ & ns & b & a & a \\
RBC & 0.026 & ns & ns & - & - & - \\
WBC & 0.002 & $<0.001$ & ns & a & a & b \\
\hline
\end{tabular}

Values (means \pm SD) were calculated by dividing each parameter value from fish i.p. injected with UV Killed Phdp by the mean value from fish i.p. injected with HBSS minus one $(n=6)$. Two-way ANOVA: $n s$ : non-significant ( $p>0.05)$; if interaction was significant, one-way ANOVA was performed. Regarding the two-way ANOVA outcomes different letters stand for significant differences among diets for the same time. 
Table 8. Fold change values of peripheral thrombocytes, lymphocytes, monocytes and neutrophils of European seabass fed dietary treatments at 4 and $24 \mathrm{~h}$ after peritoneal inflammation.

\begin{tabular}{|c|c|c|c|c|c|c|c|}
\hline \multirow{3}{*}{ Parameters } & & \multicolumn{6}{|c|}{ Dietary treatments } \\
\hline & & \multicolumn{2}{|c|}{ Control } & \multicolumn{2}{|c|}{ Tryptophan } & \multicolumn{2}{|c|}{ Methionine } \\
\hline & & $4 \mathrm{~h}$ & $24 \mathrm{~h}$ & $4 \mathrm{~h}$ & $24 \mathrm{~h}$ & $4 \mathrm{~h}$ & $24 \mathrm{~h}$ \\
\hline Thrombocytes & \multirow{4}{*}{$\begin{array}{l}0 \\
\stackrel{0}{0} \\
\frac{0}{0} \\
\frac{0}{0} \\
\text { 응 } \\
\end{array}$} & $-0.03 \pm 0.06 a b$ & $-0.13 \pm 0.10$ & $0.09 \pm 0.09 \mathrm{~b}$ & $-0.1 \pm 0.17$ & $-0.18 \pm 0.07^{a}$ & $-0.16 \pm 0.07$ \\
\hline Lymphocytes & & $-0.02 \pm 0.03^{a}$ & $0.07 \pm 0.06$ & $-0.02 \pm 0.07^{a}$ & $0.08 \pm 0.04$ & $0.17 \pm 0.06^{b}$ & $-0.01 \pm 0.06$ \\
\hline Monocytes & & $0.54 \pm 0.72$ & $0.04 \pm 0.46^{a}$ & $-0.27 \pm 0.27$ & $0.11 \pm 0.32^{a}$ & $0.0 \pm 0.50$ & $1.22 \pm 0.85$ \\
\hline Neutrophils & & $0.17 \pm 0.41$ & $0.94 \pm 0.19$ & $-0.23 \pm 0.11$ & $0.49 \pm 0.15$ & $0.08 \pm 0.31$ & $1.04 \pm 0.27$ \\
\hline
\end{tabular}

\section{Two-way ANOVA}

\begin{tabular}{ccccccc}
\hline Parameters & Time & Diet & Time $\times$ Diet & Control & Tryptophan & Methionine \\
\hline Thrombocytes & 0.017 & 0.002 & 0.050 & - & - & - \\
Lymphocytes & $\mathrm{ns}$ & $\mathrm{ns}$ & $<0.001$ & - & - & - \\
Monocytes & $\mathrm{ns}$ & 0.019 & 0.003 & - & - & - \\
Neutrophils & $<0.001$ & $<0.001$ & $\mathrm{~ns}$ & $\mathrm{~b}$ & $\mathrm{a}$ & $\mathrm{b}$ \\
\hline
\end{tabular}

Values (means \pm SD) were calculated by dividing each parameter value from fish i.p. injected with UV Killed Phdp by the mean value from fish i.p. injected with HBSS minus one $(n=6)$. Two-way ANOVA: ns: non-significant ( $p>0.05)$; if interaction was significant, one-way ANOVA was performed. Different superscript letters indicate significant differences among dietary treatments within a determined time (4 or 24 hours). Regarding the two-way ANOVA outcomes different letters stand for significant differences among diets for the same time. 


\section{Peritoneal exudates}

Total peritoneal leucocytes found in the inflamed peritoneal cavity of European seabass presented similar values among fish fed the experimental diets at $4 \mathrm{~h}$ after bacterial injection, while an increase in fish fed MET compared to fish fed CRL and TRP was observed at 24h post injection (Figure 15). Moreover, those individuals also presented an increase in circulating leucocytes from 4 to $24 \mathrm{~h}$.

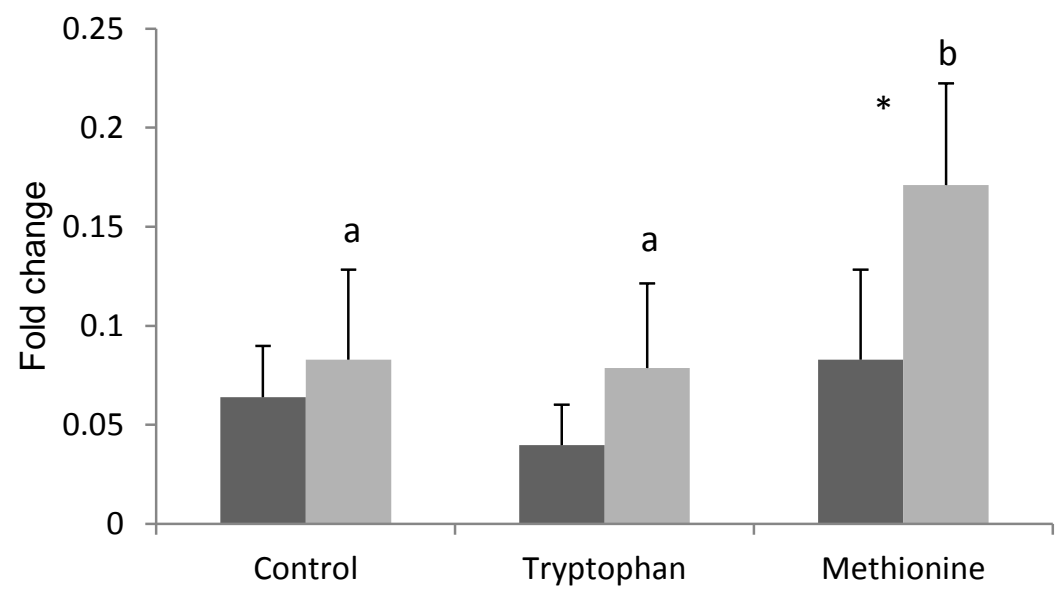

Figure 15. Fold increase of total leucocytes in the peritoneal cavity of European seabass fed dietary treatments at $4(\square)$ and 24 h ( $\square$ ) following i.p. injection with UV Killed Phdp.

Values (means \pm SD) were calculated by dividing each parameter value from fish i.p. injected with UV Killed Phdp by the mean value from fish i.p. injected with HBSS minus one $(n=6)$. P values from two-way ANOVA $(p \leq 0.05)$. If interaction was significant, one-way ANOVA was performed. Different letters stand for significant differences among diets for the same time whereas asterisk stands for significant differences in time for the same dietary treatment.

Fish fed TRP showed a decrease in lymphocyte numbers in the inflamed peritoneal cavity compared to fish fed CRL, after $24 \mathrm{~h}$ following Phdp injection (Table 9). Fish fed MET also presented increased macrophage and neutrophil numbers compared to fish fed TRP, whereas an increase of neutrophil counts with time was observed in all dietary treatments (Table 9). 
Table 9. Fold change values of peritoneal lymphocytes, macrophages and neutrophils of European seabass fed dietary treatments at 4 and $24 \mathrm{~h}$ after peritoneal inflammation.

\begin{tabular}{|c|c|c|c|c|c|c|c|}
\hline \multirow{3}{*}{\multicolumn{2}{|c|}{ Parameters }} & \multicolumn{6}{|c|}{ Dietary treatments } \\
\hline & & \multicolumn{2}{|c|}{ Control } & \multicolumn{2}{|c|}{ Tryptophan } & \multicolumn{2}{|c|}{ Methionine } \\
\hline & & $4 \mathrm{~h}$ & $24 \mathrm{~h}$ & $4 \mathrm{~h}$ & $24 \mathrm{~h}$ & $4 \mathrm{~h}$ & $24 \mathrm{~h}$ \\
\hline Lymphocytes & $\begin{array}{l}\stackrel{0}{0} \\
\frac{\mathrm{\sigma}}{\mathrm{c}}\end{array}$ & $-0.18 \pm 0.36$ & $0.31 \pm 0.22^{b}$ & $0.17 \pm 0.46$ & $-0.4 \pm 0.42^{a}$ & $-0.52 \pm 0.12$ & $-0.28 \pm 0.24 a b$ \\
\hline Macrophages & $\begin{array}{l}\text { 등 } \\
\text { 은 }\end{array}$ & $0.87 \pm 0.69$ & $1.18 \pm 0.95$ & $0.58 \pm 0.45$ & $0.47 \pm 0.78$ & $2.62 \pm 1.87$ & $2.29 \pm 2.28$ \\
\hline Neutrophils & 무 & $1.38 \pm 1.69$ & $4.59 \pm 3.88$ & $0.33 \pm 0.35$ & $3.14 \pm 2.37$ & $3.25 \pm 2.10$ & $3.34 \pm 1.43$ \\
\hline
\end{tabular}

Two-way ANOVA

\begin{tabular}{lcccccc}
\hline Parameters & Time & Diet & Time $\times$ Diet & Control & Tryptophan & Methionine \\
\hline Lymphocytes & ns & 0.020 & 0.004 & - & - & - \\
Macrophages & ns & 0.014 & ns & ab & a & b \\
Neutrophils & 0.050 & 0.035 & ns & a & a & b \\
\hline
\end{tabular}

Values (means \pm SD) were calculated by dividing each parameter value from fish i.p. injected with UV Killed Phdp by the mean value from fish i.p. injected with HBSS minus one ( $n=6)$. Two-way ANOVA: ns: non-significant ( $p>0.05)$; if interaction was significant, one-way ANOVA was performed. Different superscript letters indicate significant differences among dietary treatments within a determined time (4 or 24 hours). Regarding the two-way ANOVA outcomes different letters stand for significant differences among diets for the same time. 


\section{Innate immune response}

Plasma ACP levels increased from 4 to $24 \mathrm{~h}$ in fish fed CRL whereas no significant changes were observed among fish fed dietary treatments (Figure 16A). Lysozyme activity augmented significantly in fish fed TRP and MET compared to fish fed CRL at $4 \mathrm{~h}$ following pathogen injection, while a similar increase from 4 to $24 \mathrm{~h}$ was observed regardless of dietary treatment (Figure 16B). Plasma peroxidase levels were similar among fish fed dietary treatments at $4 \mathrm{~h}$ after inflammation whereas those values increased at $24 \mathrm{~h}$ in fish fed both $\mathrm{CRL}$ and MET, presenting the later the highest levels (Figure 16C). Plasma NO was significantly lower in fish fed TRP compared to fish fed CRL and MET and in fish fed TRP and MET compared to fish fed CRL at 4 and 24h, respectively. Moreover, NO production increased with time in specimens fed both CRL and TRP diets (Figure 16D).
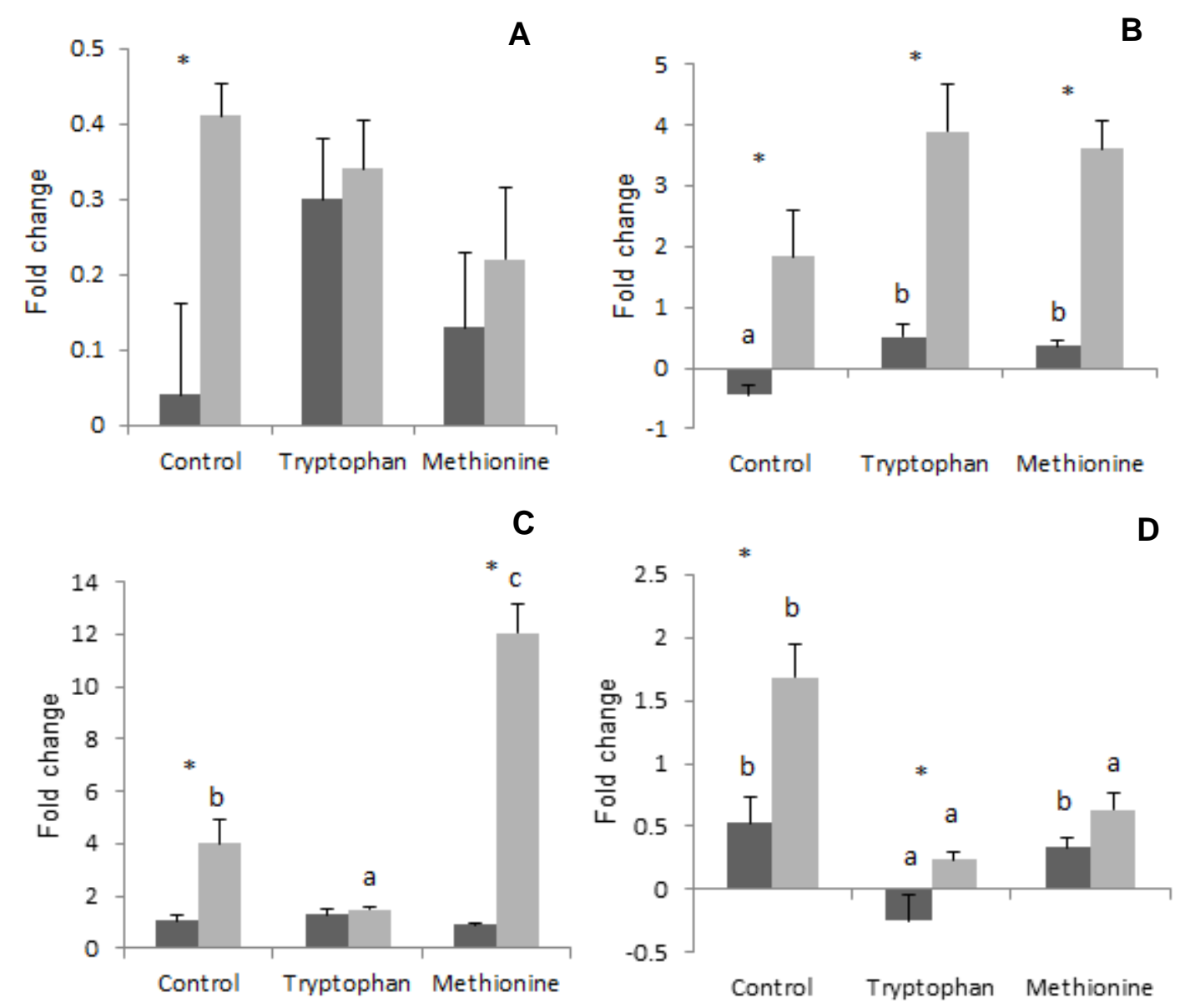

Figure 16. Plasma alternative pathway (presented as $\mathrm{ACH} 50$ units $(\mathrm{A})$; lysozyme (B); peroxidase activities (C); and nitric oxide levels (D) of European seabass fed dietary treatments at $4(\rightarrow)$ and $24(-)$ h after peritoneal inflammation. 
Values (means \pm SD) were calculated by dividing each parameter value from fish i.p. injected with UV Killed Phdp by the mean value from fish i.p. injected with HBSS minus one $(n=6)$. P values from two-way ANOVA $(p \leq 0.05)$. If interaction was significant, one-way ANOVA was performed. Different letters stand for significant differences among diets for the same time whereas asterisk stands for significant differences in time for the same dietary treatment.

The anti-protease activity of both supplemented diets was significantly higher at $4 \mathrm{~h}$ after infection relative to $C R L$, presenting fish fed TRP the highest values, while fish fed MET augmented the anti-protease activity compared to individuals fed $\mathrm{CRL}$ and TRP at 24h. Moreover, a decrease in time was observed in fish fed TRP whereas fish fed MET showed an increase in anti-protease capacity from 4 to $24 \mathrm{~h}$ (Figure 17A). Plasma bactericidal activity values decreased at $4 \mathrm{~h}$ in fish fed TRP compared to fish fed both $\mathrm{CRL}$ and MET, presenting the later the highest levels whereas individuals fed MET presented higher bactericidal capacity compared to $\mathrm{CRL}$ and TRP at $24 \mathrm{~h}$. Furthermore, bactericidal capacity increased in time regardless of dietary treatment (Figure 17B).

A

B
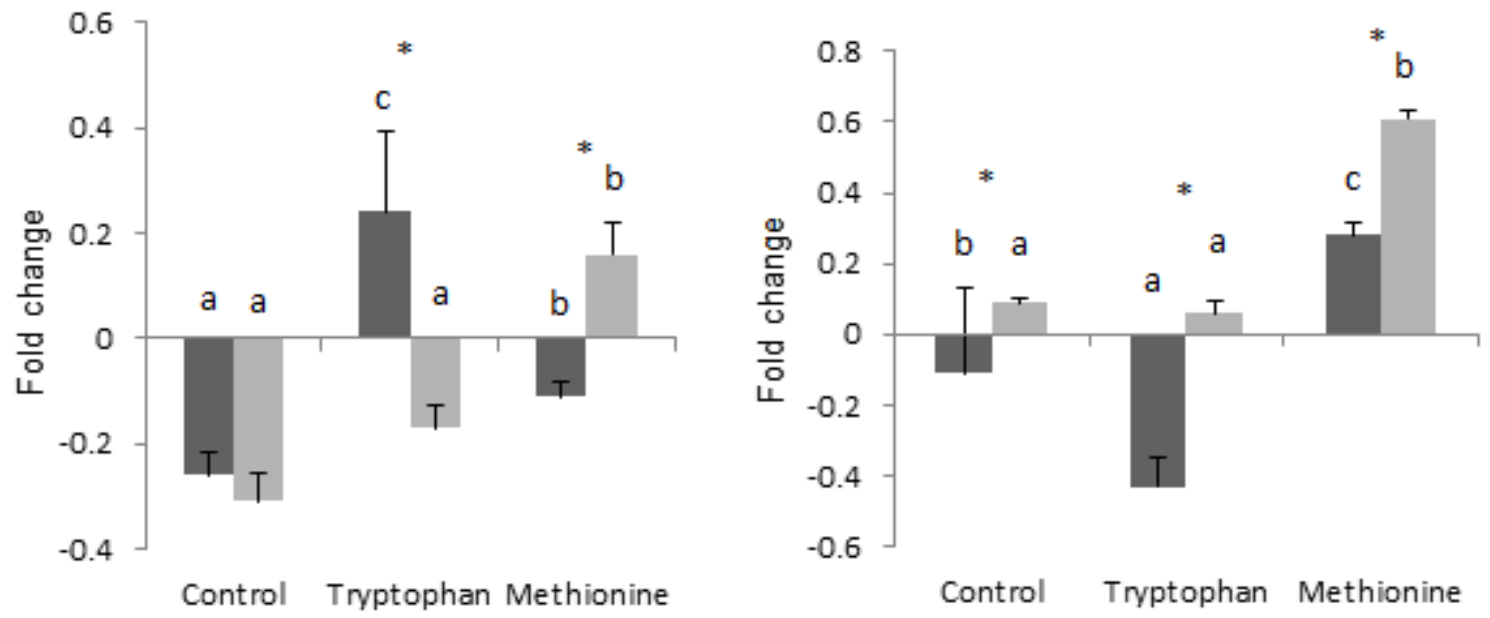

Figure 17. Plasma anti-protease $(A)$ and bactericidal activities (B) of European seabass fed dietary treatments at 4 $(\square)$ and $24(\square) h$ after peritoneal inflammation.

Values (means \pm SD) were calculated by dividing each parameter value from fish i.p. injected with UV Killed Phdp by the mean value from fish i.p. injected with HBSS minus one $(n=6)$. P values from two-way ANOVA $(p \leq 0.05)$. If interaction was significant, one-way ANOVA was performed. Different letters stand for significant differences among diets for the same time whereas asterisk stands for significant differences in time for the same dietary treatment. 


\section{Discussion}

The modulatory capacity of two indispensable $A A$, tryptophan and methionine, in the inflammatory response was here studied. The presence of the inactivated bacteria in the peritoneal cavity successfully triggered an overall increase of innate immune indicators at cellular and humoral levels. While the inflammatory response of the European seabass after experimental infection with Phdp is well known [27, 98, 28, 99, 100,18], to the best of our knowledge, this is the first study showing the modulatory effects of tryptophan and methionine supplementation on the innate immune response following stimulation with bacteria as well as the leucocyte migration dynamics to the inflammatory focus.

Grimble [60] first mentioned that cellular growth may be enhanced by polyamine supply. Although polyamines per se are not growth stimulators they may be crucial to the growth response as well as to the inflammatory process. In the present study, Trial 1 showed an enhancement of the innate immune status after 15 days feeding period in stimulated fish fed MET. When the infectious agent is added in Trial 2, the immune response was boosted and a general increase in innate immune parameters was observed. The fact that only fish fed MET presented increases in total WBC either in peripheral blood or in the inflammatory focus, is probably related to the role of methionine on cell proliferation.

As already noted by Costas at al. [89] in Senegalese sole (Solea senegalensis), blood neutrophilia and monocytosis correlated well with the increase of neutrophils and macrophages in the peritoneal cavity for seabass. Also the increase in plasma peroxidase and lysozyme are congruent with peripheral neutrophilia found [38], probably released as a result phagocytic activation [90].

Cell recruitment is supported by a significantly higher number of leucocytes at the inflammatory focus characterized by increased macrophages numbers, thereby displaying the ability of MET to improve cellular responses. Taking into account the role of methionine in the polyamines pathway as a methyl group donor [64], methionine directly participates in cell proliferation $[64,63]$ and may have allowed a stronger cell response and mobilization to the inflammatory site. Similarly, the overall antiprotease and bactericidal activity was enhanced revealing once again the MET capacity to develop a better response to infection.

Despite the fact that NO production occurs in monocytes and neutrophils $[101,48,102]$ and MET induced higher content of this peripheral phagocytic cells, the NO response may have been repressed by the higher rate of transsulfuration pathway [60]. It is known that GSH can also contribute to the activation of polymorphonuclear leucocytes and cytokine production. Consequently, cell proliferation may have been influenced not only by the increased methyl 
groups input but also by the GSH synthesis stimulation through the transsulfuration pathway [45].

The modulatory effect of tryptophan on stress [103] and its concentration decline in plasma during inflammation [70,34] gives clues about its catabolism and importance under infection situation. Firstly, tryptophan is a precursor of serotonin and melatonin at a neuroendocrine level, exerting a therapeutic effect on fish [54] improving the overall stress response [104]. Secondly, tryptophan catabolism enhances host immunity exerting direct antioxidant and antimicrobial activities [66]. The activation of IDO present in macrophages is induced by cytokines released by activated immune cells. IDO activity leads to tryptophan depletion, being unavailable for microbial biosynthesis. Moreover, IDO activity through the kynurenine pathway is responsible for superoxide anion consumption thus inhibiting the cell antioxidant activity [66].

In Trial 1 we noticed that TRP was not capable of improving both cellular and humoral parameters. However, a decrease in the cellular response was observed when bacteria were injected, presenting TRP a significantly lower peripheral monocytes and neutrophils number relative to CRL. Recent studies mentioned that IDO can be expressed not only by macrophages but also by antigen presenting cells (dendritic cells), either constitutively or after induction. These cells are responsible for exerting immune tolerance through the activation of regulatory T cells [105], suppressing the immune response of leucocytes. In the present study, the decreasing lymphocyte recruitment to the infection foci may be indicative of such an immune tolerance state. Neutrophils are the source of plasma peroxidase [38]. The low peroxidase levels found in TRP-fed fish are congruent with the low neutrophil numbers found in blood. Similarly to peroxidase, NO was also decreased in these fish. This may be explained by the inhibitory effect of the TRP metabolite $3 \mathrm{OH}$-anthranilic acid on iNOS expression [106]. Furthermore, Aydogan et al. [107] also suggested that melatonin may be responsible for the inhibition of NO production as another means whereby melatonin reduces oxidative damage under stress conditions [107].

Fish fed TRP, in the presence of an inactivated pathogen, seem to present a faster and stronger resolution of inflammation which is supported by the anti-protease activity decrease in time during infection. This scenario further suggests a tendency of tryptophan to present anti-inflammatory properties. As already shown in a porcine model, a moderate tryptophan supplementation was capable of reducing the inflammation symptoms exerting an antiinflammatory effect [108]. Moreover, the depletion of plasma tryptophan is reported during an infection situation and an over expression of IDO is usually observed. The IDO-induced 
removal of tryptophan may act as an AA deprivation and may have allowed the improved bactericidal capacity $[71,66]$. 


\section{Conclusion}

Dietary tryptophan and methionine have been proven to present important roles in the fish immune system supporting numerous pathways involved in the development and regulation of a response. To the best of our knowledge, this is the first study showing the stimulatory effects of AA on cell migration dynamics. Methionine supplementation appears to show clear effects on the European seabass immune status by improving the peripheral leucocyte response followed by higher complement activity and bactericidal capacity. Interestingly, this enhanced immunity translated in stronger cellular and humoral responses after an inflammatory situation. An enhancement of the cellular response was supported by an enhanced cellular recruitment to the inflammatory focus, which translated in increased levels of peroxidase and a higher bactericidal capacity. Methionine supplementation appears to improve the European seabass immune status thus contributing to a stronger inflammatory response, and raises the possibility to develop functional feeds as prophylactic strategies under predictable unfavourable events.

Studies assessing the effect of dietary tryptophan on the fish immune system are scarce. In the present study, a trend to augment both cell mediated immunity and humoral capacity was observed, suggesting some degree of immunostimulation. However, further studies may elucidate the potential of dietary tryptophan as immune regulator, alone (different levels) or in combination with other indispensable AA. Dietary tryptophan, through its role in the IDO activity in phagocytic and dendritic cells, may have contributed to an increased immune tolerance and anti-inflammatory response. Supplementation of this AA prior to inflammation seems to decrease the response of blood phagocytes and have no significant effect on the recruitment to the inflammatory focus. The hypothesis of immune tolerance is reinforced by a general weak humoral response.

In summary, it is suggested that methionine supplementation has a pronounced and direct influence on the innate immune response to a peritoneal inflammation, at least at the level employed in the present study. Although tryptophan supplementation may improve to some extent the immune status after 15 days of feeding, it does not translate in an improved inflammatory response, presenting even an opposite trend with anti-inflammatory effects. 


\section{References}

1. Lepage, O., Tottmar, O.,Winberg, S., 2002. Elevated dietary intake of L-tryptophan counteracts the stress-induced elevation of plasma cortisol in rainbow trout (Oncorhynchus mykiss). J Exp Biol; 205:3679-3687.

2. FAO.2012.The State of World Fisheries and Aquaculture. Nations, Food and Agriculture Organization of the United. p. 209.

3. Buentello, J.A., Reyes-Becerril, M., Romero-Geraldo, D., Ascencio-Valle, F. D., 2007. Effects of dietary arginine on hematological parameters and innate immune function of channel catfish. Journal of Aquatic Animal Health; 19:195-203.

4. FAO.2014.The State of World Fisheries and Aquaculture Nations, Food and Agriculture Organization of the United. p. 223.

5. STECF.2013.Scientific, Technical and Economic Committee for Fisheries - Summary of the 2013. (STECF-13-30)., Economic Performance Report on the EU Aquaculture sector. p. 56.

6. Ramalho, A., Dinis., M.T. Portuguese Aquaculture: current status and future prespectives, in Aquaculture EuropeSeptember 2010.

7. Relvas, P., Barton, E.D., Dubert, J., Oliveira, P.B., Peliz, A., da Silva, J.C.B., Santos, A.M.P., 2007. Physical oceanography of the western Iberia ecosystem: Latest views and challenges. Progress in Oceanography 74:149-173.

8. Pousão-Ferreira, P., 25-27 November 2008. Piscicultura em mar aberto (offshore). XI Jornadas Técnicas "O Sector Marítimo Português"; IST, APL and IPIMAR:16

9. Study of the market for aquaculture produced seabass and seabream species. Report to the European Commission DG Fisheries, April, 2004, Department of Marketing \& Institute of Aquaculture, University of Stirling. p. 94.

10. Carta de Missão, in Estrutura de Missão para a Extensão da Plataforma Continental2013, República Portuguesa.

11. Tortonese, E., 1984.Fishes of the North-Eastern Atlantic and The Mediterranean Unesco, in, Whitehead, P.J.P., Bauchot, M.L., Hureau, J:C., Nielsen, J. and Tortonese, E., (Eds.). Paris. p. 793-795.

12. Moretti, A., Pedini Fernandez-Criado, M., Cittolin, G., Guidastri, R., 1999.Manual on hatchery production of seabass and gilthead seabream. Vol. 1. Rome: FAO. pp.

13. Gorshkov, S., Meiri, I., Gordin, H. and Groshkova, G. , 2004. Culture performance of different strains and crosses of the European seabass (Dicentrarchus labrax) reared under controlled conditions at Eilat, Israel. Journal of Applied Ichthyology; 20:194-203.

14. EFSA. Scientific Opinion of the Panel on Animal Health and Welfare on a request from the European Commission on animal welfare aspects of husbandry systems for farmed European seabass and Gilthead seabream., in The EFSA Journal2008, European Food Safety Authority. p. 1-21.

15. Barazi-Yeroulanos, L. Studies and Reviews: Synthesis of Mediterranean Marine Finfish Aquaculture - A Marketing and Promotion Strategy, 2010, Food and Agriculture Organization of the United Nations: Rome.

16. Basurco, B., 2000.Offshore mariculture in Mediterranean countries, in, Muir, J. ,Basurco, B., (Eds.), Mediterranean offshore mariculture. Options Méditerranéennes : Série B. Zaragoza, Spain. p. 9-18.

17. Afonso, A., Gomes, S., da Silva, J., Marques, F.,Henrique, M., 2005. Side effects in sea bass (Dicentrarchus labrax $L$.) due to intraperitoneal vaccination against vibriosis and pasteurellosis. Fish Shellfish Immun; 19:1-16.

18. Mauri, I., Romero, A., Acerete, L., MacKenzie, S., Roher, N., Callol, A., Cano, I., Alvarez, M.C., Tort, L., 2011. Changes in complement responses in Gilthead seabream 
(Sparus aurata) and European seabass (Dicentrarchus labrax) under crowding stress, plus viral and bacterial challenges. Fish Shellfish Immun; 30:182-188.

19. Wendelaar Bonga, S.E., 1997. The stress response in fish. Physiol. Rev.; 7:591-625.

20. Barton, B.A., 2002. Stress in fishes: a diversity of responses with particular reference to changes in circulating corticosteroids. Integ. Comp. Biol.; 42:517 - 525.

21. Tort, L., 2011. Stress and immune modulation in fish. Dev Comp Immunol; 35:13661375.

22. Aragão, C., Corte-Real, J., Costas, B., Dinis, M. T., Conceicao, L. E. C., 2008. Stress response and changes in amino acid requirements in Senegalese sole (Solea senegalensis Kaup 1858). Amino Acids; 34:143-148.

23. Costas, B., Aragão, C., Mancera, J. M., Dinis, M. T., Conceicao, L. E. C., 2008. High stocking density induces crowding stress and affects amino acid metabolism in Senegalese sole Solea senegalensis (Kaup 1858) juveniles. Aquaculture Research; 39:1-9.

24. Costas, B., Conceicao, L. E. C., Aragao, C., Martos, J. A., Ruiz-Jarabo, I., Mancera, J. M., Afonso, A., 2011. Physiological responses of Senegalese sole (Solea senegalensis Kaup, 1858) after stress challenge: Effects on non-specific immune parameters, plasma free amino acids and energy metabolism. Aquaculture; 316:68-76.

25. Aragão, C., Costas, B., Vargas-Chacoff, L., Ruiz-Jarabo, I., Dinis, M.T., Mancera, J.M., Conceição, L.E.C., 2010. Changes in plasma amino acid levels in a euryhaline fish exposed to different environmental salinities. Amino Acids; 38:311- 317.

26. Mommsen, T.P., Vijayan, M. M., Moon, T. W., 1999. Cortisol in teleosts: dynamics, mechanisms of action, and metabolic regulation. Reviews in Fish Biology and Fisheries; 9:211-268.

27. Magarinõs, B., Toranzo, A.E.,Romalde, J.L., 1996. Phenotypic and pathobiological caracteristics of Pasteurella piscicida. Annu Rev Fish Dis; 6:41-64.

28. Romalde, J.L., 2002. Photobacterium damselae subsp. piscicida : an integrated view of a bacterial fish pathogen. Int Microbiol 5:3-9.

29. do Vale, A., Costa-Ramos, C., Silva, A., Silva, S.P.D., Gärtner, F., dos Santos, N.M.S.,Silva, M.T., 2007. Systemic macrophage and neutrophil destruction by secondary necrosis induced by a bacterial exotoxin in a Gram-negative septicaemia. Cellular Microbiology 9:988-1003.

30. Silva, M.T., do Vale, A., dos Santos, N.M. , 2008. Fish and apoptosis: studies in disease and pharmaceutical design. Current Pharmaceutical Design 14:170-183.

31. Kiron, V., 2012. Fish immune system and its nutritional modulation for preventive health care. Animal Feed Science and Technology; 173:111-133.

32. Wilson, R.P., 2002.Amino Acids and Proteins, Fish Nutrition. Elsevier Science. USA. p. 143-181.

33. Schreck, C.B., 1998.Immunomodulation: Endogenous factors., in, Iwama, G., Nakanishi, T., (Eds.), The Fish Immune System. Academic Press Inc. San Diego, USA.

34. Li, P., Yin, Y.L., Li, D., Kim, S.W.,Wu, G.Y., 2007. Amino acids and immune function. British Journal of Nutrition; 98:237-252.

35. Jacqueline Parkin, B.C., 2001. An overview of the immune system. The Lancet; 357:1777-89.

36. Ellis, A.E., 2001. Innate host defense mechanisms of fish against viruses and bacteria. Developmental and Comparative Immunology; 25:827-839.

37. Esteban, M.A., Cuesta, A., Chaves-Pozo, E., Meseguer, J., 2013. Influence of Melatonin on the Immune System of Fish: A Review. International Journal of Molecular Sciences; 14:7979-7999.

38. Ellis, A.E., 1999. Immunity to bacteria to fish. Fish Shellfish Immunol; 9:291-308.

39. Press, C.M. , Evensen, O., 1999. The morphology of the immune system in teleost fishes. Fish Shellfish Immunol; 9:309-318. 
40. Corbel, M.J., 1975. Immune-Response in Fish - Review. Journal of Fish Biology; 7:539-563.

41. Chistiakov, D.A., Hellemans, B.,Volckaert, F.A.M., 2007. Review of the immonology of European sea bass Dicentrarchus labrax. Vet Immunol Immunop; 117:1-16.

42. Male, D., 1986.Immunology: An Illustrated Outline, ed. Bennett, David. London: Gower Medical Publishing. pp.

43. Ellis, A.E., 2001. Innate host defense mechanisms of fish against viruses and bacteria. Dev Comp Immunol; 25:827-839.

44. Parkin, J., Cohen, B., 2001. An overview of the immune system. The Lancet; 357.

45. Alexander, J.B., Ingram, G.A., 1992. Noncellular nonspecific defence mechanisms of fish. Annual Review of Fish Diseases; 2:249-279.

46. Barton, G.M., 2008. A calculated response: control of inflammation by the innate immune system. J Clin Invest; 118:413-420.

47. Swain, P., Nayak, S.K., Nanda, P.K., Dash, S., 2008. Biological effects of bacterial lipopolysaccharide (endotoxin) in fish: a review. Fish Shellfish Immunol 25:191-201.

48. Secombes, C.J., 1996. The nonspecific immune system: cellular defense., in, Iwama, G. ,Nakanishi, T., (Eds.), The fish immune system. Academic Press Inc. San Diego, USA. p. 1-378.

49. Wu, G., 2013.Amino Acids. Biochemistry and Nutrition. Broken Sound Parkway, NW: Taylor \& Francis Group, LLC. 458 pp.

50. Costas, B., 2011. Stress mitigation in sole (Solea senegalensis) through improved nitrogen nutrition: amino acid utilization, disease resistance and immune status. PhD Thesis. University of Porto,Portugal.

51. Li, P., Mai, K.S., Trushenski, J.,Wu, G.Y., 2009. New developments in fish amino acid nutrition: towards functional and environmentally oriented aquafeeds. Amino Acids; 37:43-53.

52. Li, H., Meininger, C. J., Hawker, J. R., Haynes, T. E., Kepka-Lenhart, D., Mistry, S. K., Morris, S. M., Wu, G. Y., 2001. Regulatory role of arginase I and II in nitric oxide, polyamine, and proline syntheses in endothelial cells. American Journal of PhysiologyEndocrinology and Metabolism; 280:E75-E82.

53. Le Floc'h, N., Melchior, D.,Obled, C., 2004. Modifications of protein and amino acid metabolism during inflammation and immune system activation. Livestock Production Science; 87:37-45.

54. Conceição, L.E., Aragão, C., Dias, J., Costas, B., Terova, G., Martins, C., Tort, L., 2012. Dietary nitrogen and fish welfare. Fish Physiol Biochem; 38:119-41.

55. Milligan, C., 1997. The role of cortisol in amino acid mobilization and metabolism following exhaustive exercise in rainbow trout ( Oncorhynchus mykiss Walbaum). Fish Physiol Biochem; 16:1119- 1128.

56. Wu, G., 2009. Amino acids: metabolism, functions, and nutrition. Amino Acids 37:117.

57. Panagiotis Sakkas, L.A.J., Houdijk, J. G. M., Athanasiadou, S., Knox, D.P., Kyriazakis, I., 2013. Leucine and methionine deficiency impairs immunity to gastrointestinal parasites during lactation. British Journal of Nutrition; 109:273-282.

58. Costas, B., Conceicao, L.E.C., Dias, J., Novoa, B., Figueras, A.,Afonso, A., 2011. Dietary arginine and repeated handling increase disease resistance and modulate innate immune mechanisms of Senegalese sole (Solea senegalensis Kaup, 1858). Fish \& Shellfish Immunology; 31:838-847.

59. Rubin LL, C.C., Ribeiro ALM, Kessler A, Silva I, Trevizan L, Viola T, Raber M, Gonçalves TA, Krás R, 2007. Effects of Methionine and Arginine Dietary Levels on the Immunity of Broiler Chickens Submitted to Immunological Stimuli. Brazilian Journal of Poultry Science; 9:241 - 247. 
60. Grimble, R.F., 2002.Sulphur amino acids, glutathione and immune function, in, Calder PC, Field CJ, Gill HS. , (Eds.), Nutrition and Immune Function. CABI Publishing. New York, NY, USA. p. 133-150.

61. Wu, G.Y., Fang, Y. Z., Yang, S., Lupton, J. R., Turner, N. D., 2004. Glutathione metabolism and its implications for health. Journal of Nutrition; 134:489-492.

62. Finkelstein, J.D., 2000. Pathways and regulation of homocysteine metabolism in mammals. Semin Thromb Hemost; 26:219-225.

63. Lu, S.C., 2009. Regulation of glutathione synthesis. Molecular Aspects of Medicine; 30:42-59.

64. Grimble, R.F. , Grimble, G.K., 1998. Immunonutrition: Role of sulfur amino acids, related amino acids, and polyamines. Nutrition; 14:605-610.

65. Métayer, S., Seiliezb, I., Collina, A., Duchênea, S., Mercierc, Y., Geraertc, P.A., Tesserauda, S., 2008. Mechanisms through which sulfur amino acids control protein metabolism and oxidative status. J Nutr Biochem; 19:207-215.

66. Le Floc'h, N., Otten, W.,Merlot, E., 2011. Tryptophan metabolism, from nutrition to potentional therapeutic applications. Amino Acids; 41:1995-1205.

67. Platten M, H.P., Youssef S, Fontoura P, et al, 2005. Treatment of autoimmune neuroinflammation with a synthetic tryptophan metabolite. Science; 310:850-855.

68. Requintina, P.J., G.F. Oxenkrug, 2003. Differential effects of lipopolysaccharide on lipid peroxidation in F344N, SHR rats and BALB/c mice, and protection of melatonin and NAS against its toxicity. Ann. N.Y. Acad. Sci.; 993.

69. Hseu, J.R., Lu, F.I., Su, H.M., Wang, L.S., Tsai, C.L., Hwang, P.P., 2003. Effect of exogenous tryptophan on cannibalism, survival and growth in juvenile grouper, Epinephelus coioides. . Aquaculture; 218: $251-263$.

70. Melchior, D., Séve, B., Le Floc'h, N., 2004. Chronic lung inflamation affects plasma amino acids concentration in pigs. J .Anim. Sci; 82:1091-1099.

71. MacKenzie, C.R., Heseler, K., Muller, A.,Daubener, W., 2007. Role of indoleamine 2,3-dioxygenase in antimicrobial defence and immuno-regulation: Tryptophan depletion versus production of toxic kynurenines. Curr Drug Metab; 8:237-244.

72. Esteban, S., Nicolaus, C., Garmundi, A., Rial, R.E.V., Rodriguez, A.B., Ortega, E.,Ibars, C.B., 2004. Effect of orally administered L-tryptophan on serotonin, melatonin, and the innate immune response in the rat. Mol Cell Biochem; 267:39-46.

73. Bassity, E., Clark, T.G. , 2012. Functional Identification of Dendritic Cells in the Teleost Model, Rainbow Trout (Oncorhynchus mykiss). PLoS ONE 7.

74. Perianayagam, M.C., Oxenkrug, G.F.,Jaber, B.L., 2005. Immune-modulating effects of melatonin, $\mathrm{N}$-acetylserotonin, and $\mathrm{N}$-acetyldopamine. Neuroprotective Agents; 1053:386-393.

75. Gatlin, D.M., Barrows, F. T., Brown, P., Dabrowski, K., Gaylord, T. G., Hardy, R. W., Herman, E., Hu, G. S., Krogdahl, A., Nelson, R., Overturf, K., Rust, M., Sealey, W., Skonberg, D., Souza, E. J., Stone, D., Wilson, R., Wurtele, E., 2007. Expanding the utilization of sustainable plant products in aquafeeds: a review. Aquaculture Research; 38:551-579.

76. Cohen, S.A., Meys, M.,Tarvin, T., 1989.The pico-tag method. A manual of advance techniques for amino acid analysis. Waters Chromatography Division. Milford, MA. 124 pp.

77. De Vries, J.W., Koski, C.M., Egberg, D.C.,Larson, P.A., 1998. Comparison between a spectrophotometric and a high-pressure liquid chromatography method for determining tryptophan in food products. J Agric Food Chem; 28:896-898.

78. Kaplow, L.S., 1965. Simplified Myeloperoxidase Stain Using Benzidine Dihydrochloride. Blood-the Journal of Hematology; 26:215-\&.

79. Afonso, A., Lousada, S., Silva, J., Ellis, A.E.,Silva, M.T., 1998. Neutrophil and macrophage responses to inflammation in the peritoneal cavity of rainbow trout 
Oncorhynchus mykiss. A light and electron microscopic cytochemical study. Disease Aquatic Organisms; 34:27-37.

80. Quade, M.J., J.A., R., 1997. A rapid, direct assay to measure degranulation of bovine neutrophil primary granules. Vet Immunol Immunop; 58:239-248.

81. Saeij, J.P.J., Verburg-van Kemenade, L. B. M., van Muiswinkel, W. B., Wiegertjes, G. F., 2003. Daily handling stress reduces resistance of carp to Trypanoplasma borreli: in vitro modulatory effects of cortisol on leukocyte function and apoptosis. Dev Comp Immunol; 27:233-245.

82. Ellis, A.E., 1990.Serum antiprotesases in fish. Techniques in Fish Immunology, ed. Stolen JS., Fletcher TC., Anderson DP., Roberson BS., van Muiswinkel WB. Fair Haven: SOS. pp.

83. Stevens, M.G., Kehrli, M.E., Canning, P.C., 1991. A colorimetric assay for quantitating bovine neutrophil bactericidal activity. Vet Immunol Immunopathol; 28:45-56.

84. Zar, J.H., 1999.Biostatistical Analysis, ed. Editors, Prentice Hall International. Illinois. pp.

85. Kuang, S.Y., Xiao, W.W., Feng, L., Liu, Y., Jiang, J., Jiang, W.D., Hu, K., Li, S.H., Tang, L.,Zhou, X.Q., 2012. Effects of graded levels of dietary methionine hydroxy analogue on immune response and antioxidant status of immune organs in juvenile Jian carp (Cyprinus carpio var. Jian). Fish Shellfish Immun; 32:629-636.

86. Holland, M.C.H. , Lambris, J.D., 2002. The complement system in teleosts. Fish Shellfish Immun; 12:399-420.

87. Tang, L., Wang, G.X., Jiang, J., Feng, L., Yang, L., Li, S.H., Kuang, S.Y.,Zhou, X.Q., 2009. Effect of methionine on intestinal enzymes activities, microflora and humoral immune of juvenile Jian carp (Cyprinus carpio var. Jian). Aquacult Nutr; 15:477-483.

88. Murray, C.K. , Fletcher, T.C., 1976. Immunohistochemical localization of lysozyme in plaice (Pleuronectes-Platessa L) tissues. J Fish Biol; 9:329-334.

89. Costas, B., Rego, P.C.N.P., Simoes, I., Marques, J.F., Castro-Cunha, M.,Afonso, A., 2013. Cellular and humoral immune responses of Senegalese sole, Solea senegalensis (Kaup), following challenge with two Photobacterium damselae subsp piscicida strains from different geographical origins. J Fish Dis; 36:543-553.

90. Faurschou, M. , Borregaard, N., 2003. Neutrophil granules and secretory vesicles in inflammation. Microbes Infect; 5:1317-1327.

91. Paulsen, S.M., Engstad, R.E., Robertsen, B., 2001. Enhanced lysozyme production in Atlantic salmon (Salmo salar L.) macrophages treated with yeast B-glucan and bacterial lipopolysaccharide. Fish \& Shellfish Immunology; 11:23-37.

92. Sidransky, H., Murty, C.N., Myers, E.,Verney, E., 1983. Tryptophan-induced stimulation of hepatic ornithine decarboxylase activity in the rat. Exp Mol Pathol; 38:346-356.

93. Pendeville, H., Carpino, N., Marine, J.C., Takahashi, Y., Muller, M., Martial, J.A.,Cleveland, J.L., 2001. The ornithine decarboxylase gene is essential for cell survival during early murine development. Mol Cell Biol; 21:6549-6558.

94. Cuesta, A., Cerezuela, R., Esteban, M. A., Meseguer, J., 2008. In vivo actions of melatonin on the innate immune parameters in the teleost fish gilthead seabream. $J$ Pineal Res; 45:70-78.

95. Costas, B., Aragão, C., Dias, J., Afonso, A.,Conceicao, L.E.C., 2013. Interactive effects of a high-quality protein diet and high stocking density on the stress response and some innate immune parameters of Senegalese sole Solea senegalensis. Fish Physiol Biochem; 39:1141-1151.

96. Silva, M.T., Silva, M.N.T.,Appelberg, R., 1989. Neutrophil-macrophage cooperation in the host defence against mycobacterial infections. Microb Pathogenesis; 6:369-380 
97. Afonso, A., Ellis, A.E.,Silva, M.T., 1997. The leucocyte population of the unstimulated peritoneal cavity of rainbow trout (Oncorhynchus mykiss). Fish Shellfish Immun; 7:335348.

98. Bakopoulos, V., Volpatti, D., A., A., Galeotti, M.,Richards, R., 1997. Qualitative differences in the immune response of rabbit, mouse and sea bass, Dicentrarchus labrax, L. to Photobacterium damsela subsp. piscicida, the causative agent of fish Pasteurellosis. Fish Shellfish Immun; 7:161-174.

99. Bakopoulos, V., Volpatti, D., Gusmani, L., Galeotti, M., Adams, A.,Dimitriadis, G.D., 2003. Vaccination trials of sea bass, Dicentrarchus labrax (L.), against Photobacterium damsela subsp. piscicida, using novel vaccine mixtures. J Fish Dis; 26:77-90.

100. do Vale, A., Marques, F.,Silva, M.T., 2003. Apoptosis of sea bass (Dicentrarchus labrax L.) neutrophils and macrophages induced by experimental infection with Photobacterium damselae subsp piscicida. Fish \& Shellfish Immunology; 15:129-144.

101. Edwards, S.W., 1994.Biochemistry and physiology of the neutrophil. United States of America: Press Syndicate of the University of Cambridge. 299 pp.

102. MacMicking, J., Xie, Q.W., Nathan, C., 1997. Nitric oxide and macrophage function. Annual Review of Immunology; 15:323-350.

103. Costas, B., Aragao, C., Soengas, J.L., Miguez, J.M., Rema, P., Dias, J., Afonso, A.,Conceicao, L.E.C., 2012. Effects of dietary amino acids and repeated handling on stress response and brain monoaminergic neurotransmitters in Senegalese sole (Solea senegalensis) juveniles. Comp Biochem Phys A; 161:18-26.

104. Esteban, M.A., Rodriguez, A., Ayala, A.G.,Meseguer, J., 2004. Effects of high doses of cortisol on innate cellular immune response of seabream (Sparus aurata L.). Gen Comp Endocr; 137:89-98.

105. Sharma, M.D., Baban, B., Chandler, P., Hou, D.-Y., Singh, N., Yagita, H., Azuma, M., Blazar, B.R., Mellor, A.L.,Munn, D.H., 2007. Plasmacytoid dendritic cells from mouse tumor-draining lymph nodes directly activate mature tregs via indoleamine 2,3dioxygenase. J Clin Invest; 17:2570-2582.

106. Chiarugi, A., Rovida, E., Sbarba, P.D.,Moroni, F., 2003. Tryptophan availability selectively limits NO-synthase induction in macrophages. J Leukocyte Biol; 73:172177.

107. Aydogan, S., Yerer, M.B.,Goktas, A., 2006. Melatonin and nitric oxide. J Endocrinol Invest; 29:281-287.

108. Kim, C.J., Kovacs-Nolan, J.A., Yang, C., Archbold, T., Fan, M.Z.,Min, Y., 2010. LTryptophan exhibits therapeutic function in a porcine model of dextran sodium sulfate (DSS)-induced colitis. J Nutr Biochem Biophys Res Commun; 21:468-475. 